\title{
Regional influence of wildfires on aerosol chemistry in the western US and insights into atmospheric aging of biomass burning organic aerosol
}

\author{
Shan Zhou ${ }^{1}$, Sonya Collier ${ }^{1}$, Daniel A. Jaffe ${ }^{2,3}$, Nicole L. Briggs ${ }^{2,3,4}$, Jonathan Hee ${ }^{2,3}$, Arthur J. Sedlacek III ${ }^{5}$, \\ Lawrence Kleinman $^{5}$, Timothy B. Onasch ${ }^{6}$, and Qi Zhang ${ }^{1}$ \\ ${ }^{1}$ Department of Environmental Toxicology, University of California, Davis, CA 95616, USA \\ ${ }^{2}$ School of Science, Technology, Engineering, and Mathematics, University of Washington Bothell, Bothell, WA 98011, USA \\ ${ }^{3}$ Department of Atmospheric Sciences, University of Washington, Seattle, WA 98195, USA \\ ${ }^{4}$ Gradient, Seattle, WA 98101, USA \\ ${ }^{5}$ Environmental and Climate Sciences Department, Brookhaven National Laboratory, Upton, NY 11973, USA \\ ${ }^{6}$ Aerodyne Research Inc., Billerica, MA 01821, USA
}

Correspondence to: Qi Zhang (dkwzhang@ucdavis.edu)

Received: 19 September 2016 - Discussion started: 23 September 2016

Revised: 2 January 2017 - Accepted: 19 January 2017 - Published: 16 February 2017

\begin{abstract}
Biomass burning (BB) is one of the most important contributors to atmospheric aerosols on a global scale, and wildfires are a large source of emissions that impact regional air quality and global climate. As part of the Biomass Burning Observation Project (BBOP) field campaign in summer 2013, we deployed a high-resolution timeof-flight aerosol mass spectrometer (HR-AMS) coupled with a thermodenuder at the Mt. Bachelor Observatory (MBO, $\sim 2.8 \mathrm{~km}$ above sea level) to characterize the impact of wildfire emissions on aerosol loading and properties in the $\mathrm{Pa}$ cific Northwest region of the United States. MBO represents a remote background site in the western US, and it is frequently influenced by transported wildfire plumes during summer. Very clean conditions were observed at this site during periods without $\mathrm{BB}$ influence where the $5 \mathrm{~min}$ average $( \pm 1 \sigma)$ concentration of non-refractory submicron aerosols $\left(\mathrm{NR}-\mathrm{PM}_{1}\right)$ was $3.7 \pm 4.2 \mu \mathrm{g} \mathrm{m}^{-3}$. Aerosol concentration increased substantially (reaching up to $210 \mu \mathrm{g} \mathrm{m}^{-3}$ of NR-PM ${ }_{1}$ ) for periods impacted by transported BB plumes, and aerosol composition was overwhelmingly organic. Based on positive matrix factorization (PMF) of the HR-AMS data, three types of $\mathrm{BB}$ organic aerosol (BBOA) were identified, including a fresh, semivolatile BBOA-1 $(\mathrm{O} / \mathrm{C}=0.35 ; 20 \%$ of $\mathrm{OA}$ mass) that correlated well with ammonium nitrate; an intermediately oxidized BBOA-2 $(\mathrm{O} / \mathrm{C}=0.60 ; 17 \%$ of
\end{abstract}

OA mass); and a highly oxidized BBOA-3 $(\mathrm{O} / \mathrm{C}=1.06$; $31 \%$ of OA mass) that showed very low volatility with only $\sim 40 \%$ mass loss at $200{ }^{\circ} \mathrm{C}$. The remaining $32 \%$ of the OA mass was attributed to a boundary layer (BL) oxygenated OA (BL-OOA; O / C $=0.69$ ) representing OA influenced by BL dynamics and a low-volatility oxygenated OA (LV-OOA; $\mathrm{O} / \mathrm{C}=1.09$ ) representing regional aerosols in the free troposphere. The mass spectrum of BBOA-3 resembled that of LV-OOA and had negligible contributions from the HR-AMS BB tracer ions $-\mathrm{C}_{2} \mathrm{H}_{4} \mathrm{O}_{2}^{+}(m / z=60.021)$ and $\mathrm{C}_{3} \mathrm{H}_{5} \mathrm{O}_{2}^{+}$ $(m / z=73.029)$; nevertheless, it was unambiguously related to wildfire emissions. This finding highlights the possibility that the influence of $\mathrm{BB}$ emission could be underestimated in regional air masses where highly oxidized BBOA (e.g., BBOA-3) might be a significant aerosol component but where primary BBOA tracers, such as levoglucosan, are depleted. We also examined OA chemical evolution for persistent BB plume events originating from a single fire source and found that longer solar radiation led to higher mass fraction of the chemically aged BBOA-2 and BBOA-3 and more oxidized aerosol. However, an analysis of the enhancement ratios of OA relative to $\mathrm{CO}(\triangle \mathrm{OA} / \triangle \mathrm{CO})$ showed little difference between $\mathrm{BB}$ plumes transported primarily at night versus during the day, despite evidence of substantial chemical transformation in OA induced by photooxidation. These 
results indicate negligible net OA production in photochemically aged wildfire plumes observed in this study, for which a possible reason is that SOA formation was almost entirely balanced by BBOA volatilization. Nevertheless, the formation and chemical transformation of BBOA during atmospheric transport can significantly influence downwind sites with important implications for health and climate.

\section{Introduction}

Biomass burning (BB) is estimated to be the largest source of primary carbonaceous aerosols and a major source of reactive trace gases in the Earth's atmosphere (Bond et al., 2004; Akagi et al., 2011). Emissions from wildfires and other BB sources, such as residential wood combustion and agricultural burning, have been shown to affect the global radiation budget (IPCC, 2013) and degrade air quality in both rural areas and populated locations (e.g., Jaffe et al., 2008; Jaffe and Wigder, 2012). The environmental impacts of BB emissions are strongly correlated with the chemical, optical, and microphysical properties of BB aerosols, which are in turn dependent in a complex manner on fuel type, combustion phase, and atmospheric aging of emitted particles and gas species (e.g., Petters et al., 2009; Liu et al., 2014; Collier et al., 2016).

Organic compounds are a dominant component of BB aerosols (Bond et al., 2004; De Gouw and Jimenez, 2009), but the chemical and physical properties of primary organic aerosol (POA) released directly from burning and secondary organic aerosol (SOA) formed from gaseous precursors emitted by BB are dramatically different. For example, BB POA tends to be semivolatile, smaller in size, and composed of less oxidized compounds, whereas SOA from BB is generally more oxidized, larger in size, and less volatile (Abel et al., 2003; Heringa et al., 2011; May et al., 2013). Furthermore, aerosol composition, optical properties, and hygroscopicity have been found to change substantially in BB plumes undergoing photooxidation and cloud processing, and the changes are mostly driven by the organic fraction (Abel et al., 2003; De Gouw et al., 2006; Engelhart et al., 2012; Gilardoni et al., 2016). Understanding the chemical properties and atmospheric processing of organic aerosols (OAs) from BB sources (i.e., BBOA) is thus crucial for improving our ability to quantitatively assess and predict the impacts of $\mathrm{BB}$ emissions on climate and air quality. However, the chemical processing of BBOA is highly complex, and the net effect of aging on BBOA mass is highly variable. For example, while several laboratory studies reported substantial formation of SOA during chamber aging, others observed a very small increase or even a decrease of BBOA mass (Grieshop et al., 2009; Cubison et al., 2011; Hennigan et al., 2011; Heringa et al., 2011; Ortega et al., 2013). Field studies have also observed enhancement (Yokelson et al., 2009; DeCarlo et al., 2010), depletion (e.g., Akagi et al., 2012; Jolleys et al., 2015), or no change (Brito et al., 2014; May et al., 2015) of dilution-adjusted OA mass in BB plumes after emissions.

In order to decipher what factors affect BBOA evolution and reconcile discrepancies in previous laboratory and atmospheric observational results, the US Department of Energy (DOE) sponsored the Biomass Burning Observation Project (BBOP) campaign, which combined aircraft-based measurements with mountaintop observations to characterize the downstream evolution of the chemical, microphysical, and optical properties of carbonaceous aerosol generated by BB. Wildfires across the western US have been linked to increased $\mathrm{PM}_{2.5}$ concentrations at various receptor sites (Jaffe et al., 2008) and high-pollution episodes that exceeded the National Ambient Air Quality Standards (Jaffe and Wigder, 2012). Furthermore, due to changes in precipitation, temperature, and other meteorological conditions as a result of climate change, wildfire activities in this region have been increasing (Westerling et al., 2006; Dennison et al., 2014) and are predicted to increase summertime OA concentration by $40 \%$ from 2000 to 2050 (Spracklen et al., 2009).

A large number of wildfire events originating in the western US were observed during BBOP from the Mount Bachelor Observatory (MBO) - a remote mountaintop site that serves to characterize western US background conditions and is frequently impacted by transported BB plumes during the summer fire season (Wigder et al., 2013). Continuous measurements of BB plumes at MBO allow for the study of BBOA with different source, age, and formation pathways under realistic atmospheric conditions and can provide rich data for evaluating the impact of BB emissions on regional aerosol properties and elucidating their atmospheric aging processes. A number of recent studies were conducted at fixed locations in the western US and investigated impacts of BB on ozone, gaseous nitrogen species, and organic and elemental carbon (e.g., Wigder et al., 2013; Timonen et al., 2014; Hallar et al., 2015). Yet only a few ground-based measurements have examined the chemical composition and evolution of BBOA, including a filter-based study of wildfire aerosols in Yosemite National Park (Engling et al., 2006) and a single-particle mass spectrometry study on the mixing state and aging of particles during the 2007 San Diego wildfires (Zauscher et al., 2013).

In this study, we provide an overview of the chemical and physical characteristics of non-refractory submicrometer particles (NR-PM $)_{1}$ at $\mathrm{MBO}$ and examine the changes in ambient aerosol concentration and composition influenced by $\mathrm{BB}$ emissions. The sources of $\mathrm{OA}$ are investigated via factor analysis of the high-resolution time-of-flight aerosol mass spectrometer (HR-AMS), and the aging of BBOA is discussed via combining real-time measurements with trajectory analysis. We also examine the enhancement and chemical transformation of $\mathrm{OA}$ in $\mathrm{BB}$ plumes transported during daytime and nighttime, respectively. 
(a)

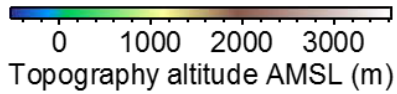

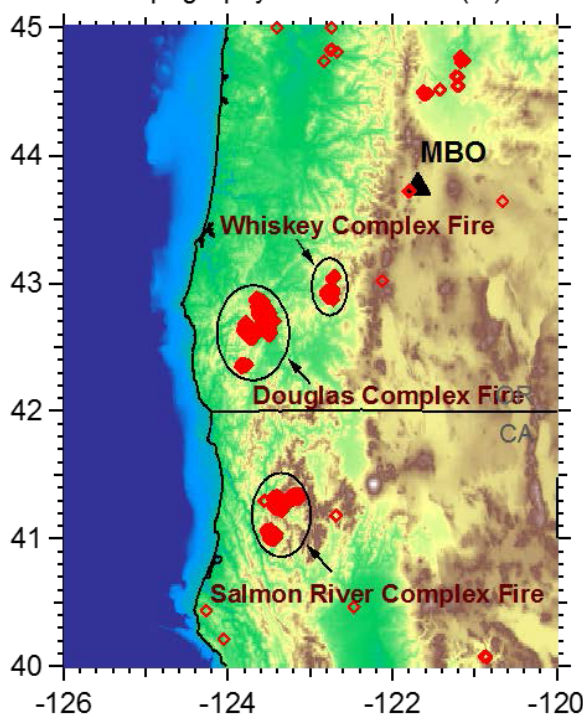

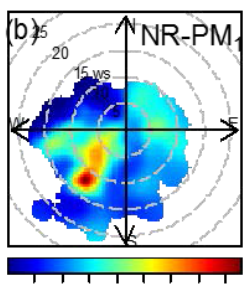

510152025303540

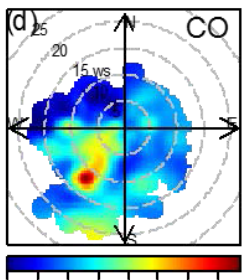

80100120140160180200220 (c) Avg $=15.1 \mu \mathrm{g} \mathrm{m}^{-3}$
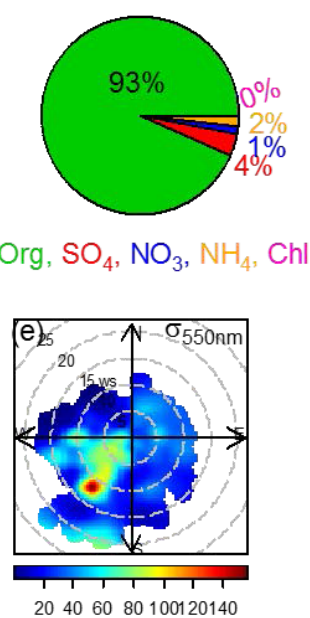

Figure 1. (a) Map with MBO (black solid triangle) and wildfires detected by MODIS (red open diamonds) in the US Pacific Northwest from 25 July to 25 August 2013. Three fire complexes - Whiskey Complex fire (WCF), Douglas Complex fire (DCF), and Salmon River Complex fire (SRCF) - are highlighted with black circles. Bivariate polar plots of (b) NR-PM 1 concentrations (in $\mu g \mathrm{~m}^{-3}$ ), (d) submicrometer aerosol light scattering at $550 \mathrm{~nm}\left(\sigma_{550 \mathrm{~nm}}\right.$ in $\left.\mathrm{Mm}^{-1}\right)$, and (e) CO mixing ratio (in ppbv) during the sampling period. (c) Average NR-PM composition for the sampling period.

\section{Experimental methods}

\subsection{Sampling site and wildfires in the vicinity}

The Mt. Bachelor Observatory $\left(43.981^{\circ} \mathrm{N} 121.691^{\circ} \mathrm{W}\right.$; Fig. 1) is situated on the summit of Mt. Bachelor $(\sim 2.8 \mathrm{~km}$ a.s.1.), an isolated volcanic peak in the Deschutes National (coniferous) Forest in central Oregon. The nearest populated areas are Bend (pop. $\sim 80000$ ), $31 \mathrm{~km}$ to the east, and Redmond (pop. $\sim 26000$ ), $53 \mathrm{~km}$ northeast of MBO. Due to its high elevation and distance from local pollution sources, MBO is a remote background site in the western US well positioned for sampling of background freetropospheric air and observation of long-range transport of Asian plumes and North American wildfires (Weiss-Penzias et al., 2006; Wigder et al., 2013; Briggs et al., 2016).

During the sampling period from 25 July to 25 August 2013, various active wildfires in northern California and southeastern and central Oregon were detected by the Moderate Resolution Imaging Spectroradiometer (MODIS) satellite (https://firms.modaps.eosdis.nasa.gov) (Fig. 1). Three intense fires - the Salmon River Complex fire (SRCF), Whiskey Complex fire (WCF), and Douglas Complex fire (DCF) - were active for a majority of the time during this study and hence were identified as major fires in the region.

\subsection{Real-time measurements at MBO}

Continuous observations at $\mathrm{MBO}$ included submicron aerosol light scattering (TSI nephelometer; 450, 550, and $700 \mathrm{~nm}$ ) and absorption (Radiance Research particle soot absorption radiometer (PSAP); 467, 530, and $660 \mathrm{~nm}$ ), elemental and organic carbon (Sunset Lab), $\mathrm{CO}$ and $\mathrm{CO}_{2}$ (Picarro cavity ring-down spectroscopy), $\mathrm{O}_{3}$ (Dasibi), $\mathrm{NO}_{x}$ (Air Quality Design two-channel chemiluminescence), $\mathrm{NO}_{y}$ (chemiluminescence), peroxyacetyl nitrate (PAN; custom gas chromatograph), and meteorological parameters (e.g., Weiss-Penzias et al., 2006; Briggs et al., 2016). Data reported in this study are 5 min averages. During this study, an HRAMS (DeCarlo et al., 2006) was deployed downstream of a thermodenuder (TD) to measure the size-resolved composition and volatility of NR-PM $\mathrm{P}_{1}$. These are the first real-time aerosol chemical measurements at MBO. The TD consists of a heated tube followed by a heated adsorption section that uses carbon cloth to prevent recondensation of organic vapors (Fierz et al., 2007). The TD was automated using a custom program to step through 12 different temperatures ranging from 30 to $200^{\circ} \mathrm{C}$, at $10 \mathrm{~min}$ time intervals. Changes in mass and chemical composition of NR-PM $\mathrm{PM}_{1}$ as a result of aerosol evaporation were quantified by the HR-AMS by alternating sampling between the TD and the bypass (BP) ambient sampling mode every $5 \mathrm{~min}$. During BP mode, the temperature in the heated section ramped up to the next setting and reached thermal stability before switching back to 
TD mode. The switching between sampling modes was triggered by a digital output signal from the HR-AMS which was synchronized to the HR-AMS averaging intervals and was achieved using an actuated three-way ball valve. Aerosol residence time in the TD was $8.2 \mathrm{~s}$ at the experimental flow rate $\left(1.1 \mathrm{~L} \mathrm{~min}^{-1}\right)$. Particle losses within the TD mode $(\sim 5 \%)$ due to diffusional and thermophoretic forces were quantified based on the behavior of ammonium sulfate.

\subsection{HR-AMS data analysis}

The HR-AMS was operated in the ion optical "V-mode" with reduced micro-channel plate bandwidth due to signal interference at $\mathrm{MBO}$, and it was calibrated following standard protocols described in detail in Collier et al. (2016). Data analyses were performed utilizing AMS analysis toolkit SQUIRREL v1.53 (SeQUential Igor data RetRiEvaL) and PIKA v1.12 (Peak Integration by Key Analysis) in Igor Pro 6.34A (Wavemetrics, Inc., Lake Oswego, OR). Default relative ionization efficiency (RIE) values were assumed for organics (1.4), nitrate (1.1), and chloride (1.3), while an RIE value of 5 was determined for ammonium and 1.32 for sulfate following the analysis of pure $\mathrm{NH}_{4} \mathrm{NO}_{3}$ and $\left(\mathrm{NH}_{4}\right)_{2} \mathrm{SO}_{4}$, respectively. A time- and composition-dependent collection efficiency (CE) was applied based on the algorithm by Middlebrook et al. (2012), leading to an average $( \pm 1 \sigma) \mathrm{CE}$ of $0.56( \pm 0.12)$. Time-dependent gas phase $\mathrm{CO}_{2}^{+}$subtraction was performed to improve the determination of OA mass concentration and mass spectra, which is critical for lowOA-concentration periods (Collier and Zhang, 2013). The mass concentrations of ammonium, nitrate, chloride, and sulfate were determined from PIKA analysis of the highresolution mass spectra (HRMS), whereas organic concentrations came from SQUIRREL analysis of the unit mass resolution (UMR) data after adjusting the fragmentation table (Allan et al., 2004) to properly represent the organic signals at $m / z$ 's that are contributed significantly by inorganic or air signals. The detection limits of organics, sulfate, nitrate, ammonium, and chloride, defined as 3 times the standard deviations $(3 \sigma)$ of the corresponding signals in particle-free ambient air, were 28.1, 4.5, 2.3, 9.6, and $3.0 \mathrm{ng} \mathrm{m}^{-3}$, respectively, for an averaging time of $5 \mathrm{~min}$. Atomic oxygen-to-carbon $(\mathrm{O} / \mathrm{C})$ and hydrogen-to-carbon $(\mathrm{H} / \mathrm{C})$ ratios and the organic mass-to-carbon (OM / OC) ratio were determined using the improved-ambient (IA) method (Canagaratna et al., 2015). We also reported the ratios determined using the previously published Aiken-Ambient (AA) method (Aiken et al., 2008) in order to compare with literature results. As shown in Fig. S1 in the Supplement, the O/C, H/C, and $\mathrm{OM} / \mathrm{OC}$ values determined from the two methods correlate tightly $\left(r^{2}=0.99\right)$, and the IA method reports 29,5 , and $31 \%$, respectively, higher values than the AA method.

Positive matrix factorization (PMF) was executed using the PMF2 algorithm (Paatero and Tapper, 1994) in the PMF Evaluation Tool (PET) v2.05 program (Ulbrich et al., 2009).
The spectral matrices of organic and inorganic species were combined (Sun et al., 2012), and the ion signals were expressed in nitrate-equivalent concentrations. Periods with organic concentration below $1.5 \mu \mathrm{g} \mathrm{m}^{-3}(\sim 20 \%$ of the total data points), which hindered the model to converge due to increased rotational ambiguity, were excluded from PMF analysis. The HRMS of organic ions at $m / z, 12-180$ and the UMR signals at $m / z$ 181-350 were included. For inorganics, only the major ions for each species were included, i.e., $\mathrm{SO}^{+}$, $\mathrm{SO}_{2}^{+}, \mathrm{HSO}_{2}^{+}, \mathrm{SO}_{3}^{+}, \mathrm{HSO}_{3}^{+}$, and $\mathrm{H}_{2} \mathrm{SO}_{4}^{+}$for sulfate; $\mathrm{NO}^{+}$and $\mathrm{NO}_{2}^{+}$for nitrate; $\mathrm{NH}^{+}, \mathrm{NH}_{2}^{+}$, and $\mathrm{NH}_{3}^{+}$for ammonium; and $\mathrm{HCl}^{+}$for chloride. $\mathrm{Cl}^{+}$was not included due to low $S / N$. Data preparation prior to PMF analysis followed the steps outlined in Table 1 of Zhang et al. (2011). After PMF analysis, the mass concentration of each OA factor was derived from the sum of organic signals in the corresponding mass spectrum after applying the RIE $(=1.4)$ for organics and the time-dependent CE determined based on aerosol composition (see previous discussion). The solutions for three to eight factors were explored with varying rotational parameters $(-0.5 \leq$ FPEAK $\leq 0.5$, in increments of 0.1$)$. After a detailed evaluation of mass spectral profiles, temporal trends, diurnal variations, and correlations with external tracers, the five-factor solution with FPEAK $=0$ was chosen. The diagnostic information for the five-factor solution is shown in Fig. S2. In comparison, the four-factor solution resulted in large residual signals, indicating that an additional factor was needed to explain the variation in the data, whereas the sixfactor solution showed indications of factor splitting, suggesting that too many factors were introduced (Fig. S3). PMF was also performed on the organic spectra only but was not able to resolve two types of oxygenated OA (OOA; see more detailed discussions in Sect. S1 of the Supplement).

The concentrations of OA factors at different TD temperatures were determined via multivariate linear regression of the HRMS of OA after TD against the HRMS of the five OA factors determined from PMF of the ambient OA data following the procedures given in Zhou et al. (2016). The mass fraction remaining (MFR) of a factor at each TD temperature was then determined as the slope from orthogonal fit between the time series after TD and the ambient time series. The MFR of a factor at each TD temperature was then determined as the slope from orthogonal fit between the time series after TD and the ambient time series. Note that the uncertainties of the MFR likely increase with TD temperature, especially for more volatile species, possibly due to changes in particle collection efficiency and decreased concentration (thus lower $S / N$ ). Indeed, as shown in Fig. S4, the correlation coefficients between the TD-processed aerosol species and the ambient data decreased with increased TD temperature. Thermograms, which describe the MFR as a function of temperature, have been corrected for particle losses in the TD mode. Aerosol data reported here have all been converted 
to concentrations at standard temperature and pressure (STP, $273 \mathrm{~K}, 1 \mathrm{~atm})$.

\subsection{Back-trajectory analysis and calculations of plume transport time and cumulative solar radiation}

The HYbrid Single Particle Lagrangian Integrated Trajectory (HYSPLIT) model backward air mass trajectories (Draxler and Hess, 1998) were initiated from MBO at $1 \mathrm{~h}$ intervals throughout the campaign period. Three-day backward trajectories using the $40 \mathrm{~km}$ resolution US Eta Data Assimilation System (EDAS) meteorological data (http://ready.arl.noaa. gov/HYSPLIT.php) were calculated at a starting height of $1500 \mathrm{~m}$ above ground level. Meteorological variables (e.g., solar radiation and relative humidity, $\mathrm{RH}$ ) along the trajectories were also model outputs. By overlapping the back trajectories with MODIS fire hotspots, we estimated the transport times for BB plumes that unambiguously passed over active fire sources (Collier et al., 2016). In addition, we also estimated the cumulative solar radiation exposure and average $\mathrm{RH}$ for these plumes during the period between emission at fire source and arrival at MBO.

\section{Results and discussions}

\subsection{Observations of wildfire-influenced air masses at MBO}

Figure 2 provides an overview of the meteorological conditions, trace gases mixing ratios, and aerosol concentration and composition during the sampling period (25 July25 August 2013). The summit air was cool (average temperature of $11.2 \pm 4{ }^{\circ} \mathrm{C}$ ) and dry (average RH of $46 \pm 21 \%$ ), although there were periods (e.g., 16 and 23 August) when MBO was in low clouds and measured RH reached $98 \%$. Wind was generally strong (average $=5.7 \pm 3.4 \mathrm{~m} \mathrm{~s}^{-1}$ ) with a dominant flow from the west and southwest direction, which provides suitable conditions for long-range transport of fire smoke from northern California and southwest Oregon. Indeed, the bivariate polar plots of total NR-PM 1 , submicrometer aerosol light scattering at $550 \mathrm{~nm}\left(\sigma_{550 \mathrm{~nm}}\right)$, and $\mathrm{CO}$ (Fig. 1b, d, and e) calculated using the OpenAir software (Carslaw and Ropkins, 2012) all show the highest values at a wind speed of $\sim 13 \mathrm{~m} \mathrm{~s}^{-1}$ from the southwest direction, where the major complex fires were located (Fig. 1a).

The average NR-PM ${ }_{1}$ concentration during the entire sampling period was $15.1 \mathrm{\mu g} \mathrm{m}^{-3}$, and $93 \%$ of it was contributed by organics (Fig. 1c). However, aerosol concentrations and composition changed dynamically. Clean periods of low concentrations of aerosol (NR-PM $\left.1<10 \mu \mathrm{g} \mathrm{m}^{-3}\right)$ and gas phase pollutants (e.g., $\mathrm{CO}, \mathrm{NO}_{y}$, and PAN) were observed for the first week of sampling (25-30 July) and during 18-21 August (Fig. 2d-f). During these periods, ammonium sulfate contributed up to $90 \%$ of the NR-PM 1 mass (Fig. $2 \mathrm{~g}$ ), and the OA spectra showed low abundances of $\mathrm{C}_{2} \mathrm{H}_{4} \mathrm{O}_{2}^{+}(\mathrm{m} / \mathrm{z}=$

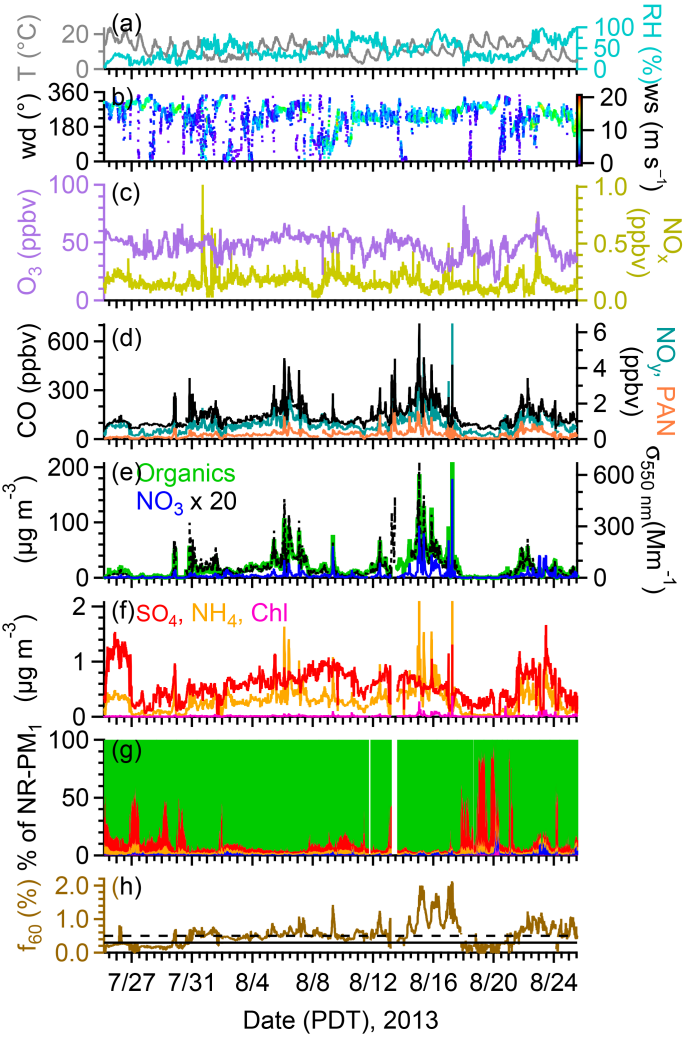

Figure 2. Time series of (a) temperature $(T)$ and relative humidity (RH); (b) wind direction (WD) colored by wind speed (WS); (c) mixing ratios of $\mathrm{O}_{3}$ and $\mathrm{NO}_{x}$; (d) mixing ratios of $\mathrm{CO}, \mathrm{NO}_{y}$, and PAN; $(\mathbf{e}, \mathbf{f})$ mass concentrations of NR-PM 1 species and $\sigma_{550 \mathrm{~nm}}$ in $\operatorname{STP}(T=273 \mathrm{~K}, P=1013.25 \mathrm{hPa})$; (g) NR-PM 1 composition; and (h) $f_{60}\left(=\mathrm{C}_{2} \mathrm{H}_{4} \mathrm{O}_{2}^{+} / \mathrm{OA}\right)$. The solid and broken lines in panel (h) indicate $f_{60}=0.3 \%$ and $f_{60}=0.5 \%$, respectively.

60.021) and $\mathrm{C}_{3} \mathrm{H}_{5} \mathrm{O}_{2}^{+}(\mathrm{m} / z=73.029)$, which are ion fragments of anhydrous sugar (e.g., levoglucosan) and HR-AMS tracers for BB (Alfarra et al., 2007). $f_{60}$, which is defined as the fraction of the signal at $m / z 60\left(\right.$ mostly $\left.\mathrm{C}_{2} \mathrm{H}_{4} \mathrm{O}_{2}^{+}\right)$in OA spectrum, was generally below $0.3 \%$ (Fig. $2 \mathrm{~h}$ ), indicating minimal BB influence during "clean" periods (Cubison et al., 2011).

In contrast, the other periods were characterized by higher $f_{60}$ (up to $2 \%$ ), elevated NR-PM 1 concentration (up to $\sim 210 \mu \mathrm{g} \mathrm{m}^{-3}$ ), and larger OA fraction (generally $>90 \%$ of NR-PM ${ }_{1}$; Fig. $2 \mathrm{e}-\mathrm{g}$ ). In addition, $\sigma_{550 \mathrm{~nm}}$ (up to $\sim 670 \mathrm{Mm}^{-1}$ ), $\mathrm{CO}$ (up to $\sim 700 \mathrm{ppbv}$ ), $\mathrm{NO}_{y}$ (up to $\sim 6.5 \mathrm{ppbv}$ ), and PAN (up to $\sim 2.2 \mathrm{ppbv}$ ) all increased dramatically during high- $f_{60}$ periods (Fig. $2 \mathrm{~d}-\mathrm{e}$ ). In fact, the time series of all these parameters correlated tightly, with Pearson's $r^{2}$ in the range of 0.66-0.94 (Fig. S5). These observations highlight the frequent and significant impacts of wildfire emissions on air quality and atmospheric chemistry in the Pacific Northwest region during this study. Note that potassium $(\mathrm{K})$ is frequently used as a tracer for BB aerosol, 
and the presence of $\mathrm{K}$ in aerosol particles was clearly observed during high-loading periods. However, $\mathrm{K}$ concentration in aerosol was overall very low and noisy throughout this study (Fig. S6), indicating low K contents in wildfire emissions in the western US. Similarly, Maudlin et al. (2015) observed no strong enhancement of $\mathrm{K}$ in wildfire smoke originated from California and Oregon and concluded that it is not a reliable tracer for $\mathrm{BB}$ in this region.

\subsection{Impacts of wildfires on regional aerosol characteristics}

\subsubsection{Changes of aerosol concentration and composition due to wildfires}

Using $f_{60}$ as an index for the influence of $\mathrm{BB}$ emissions on OA composition, we divided the entire campaign into three regimes: (1) "No BB" for periods with negligible BB influence and $f_{60} \leq 0.3 \%$; (2) "BB Infl" for periods with detectable BB influences and moderately elevated $f_{60}$ values $(0.3-0.5 \%)$; and (3) "BB Plm" for periods with $f_{60}>0.5 \%$, indicating intense and less processed BB events. Note that periods with very low $\mathrm{OA}$ concentrations $\left(<1 \mu \mathrm{g} \mathrm{m}^{-3}\right)$, e.g., 18-21 August, were classified as No BB regardless of the nominal $f_{60}$ values. The average $( \pm 1 \sigma) f_{60}$ values were $0.18 \pm 0.10,0.43 \pm 0.05$ and $0.77 \pm 0.29 \%$ for No BB, BB Infl, and BB Plm periods, respectively (Fig. 3 and Table S1). Similarly, the average mixing ratios of $\mathrm{CO}$, a gaseous pollutant released from combustion, increased from $87.8 \pm 17.9$ ppbv during No BB to $121.4 \pm 24.8$ ppbv during BB Infl and $178.3 \pm 68.8$ ppbv during BB Plm periods.

Figure 3 shows the comparisons of gas and particle phase properties among the three regimes to illustrate the strong effects that wildfires have on gases and aerosol composition in the Pacific Northwest region. For example, the average NR-PM 1 concentration was only $3.7( \pm 4.2) \mu \mathrm{g} \mathrm{m}^{-3}$ during No BB but increased by $\sim 4$ and $\sim 7$ times, respectively, during BB Infl $\left(13.4 \pm 7.1 \mu \mathrm{g} \mathrm{m}^{-3}\right)$ and BB Plm $\left(25.7 \pm 19.9 \mu \mathrm{g} \mathrm{m}^{-3}\right)$ periods. Aerosol measured at MBO during BB Plm periods was predominantly organic $(94.6 \%$ of NR-PM 1 mass; Fig. S7c). The fraction of $\mathrm{OA}$ in $\mathrm{BB}$ aerosols may be fuel dependent; for instance, high values have been reported for ponderosa pine smoke emissions (99\%) (Lewis et al., 2009), and somewhat lower values have been reported for forest fires in southwestern Amazon (93\%) (Artaxo et al., 2013) and North America boreal forests (87\%) (Kondo et al., 2011), and agricultural fires in west Africa (85\%) (Capes et al., 2008). Even lower values were observed in eastern Mediterranean wildfires (51.4\%) (Bougiatioti et al., 2014) and Asian fires (60\%) (Kondo et al., 2011). Since temperate evergreen vegetation was likely the dominant fuel during this campaign, the high $\mathrm{OA} / \mathrm{PM}_{1}$ ratio observed in this study appears consistent with those of ponderosa pine.

In addition to OA, concentrations of nitrate, ammonium, and chloride all showed substantial increases that correlated

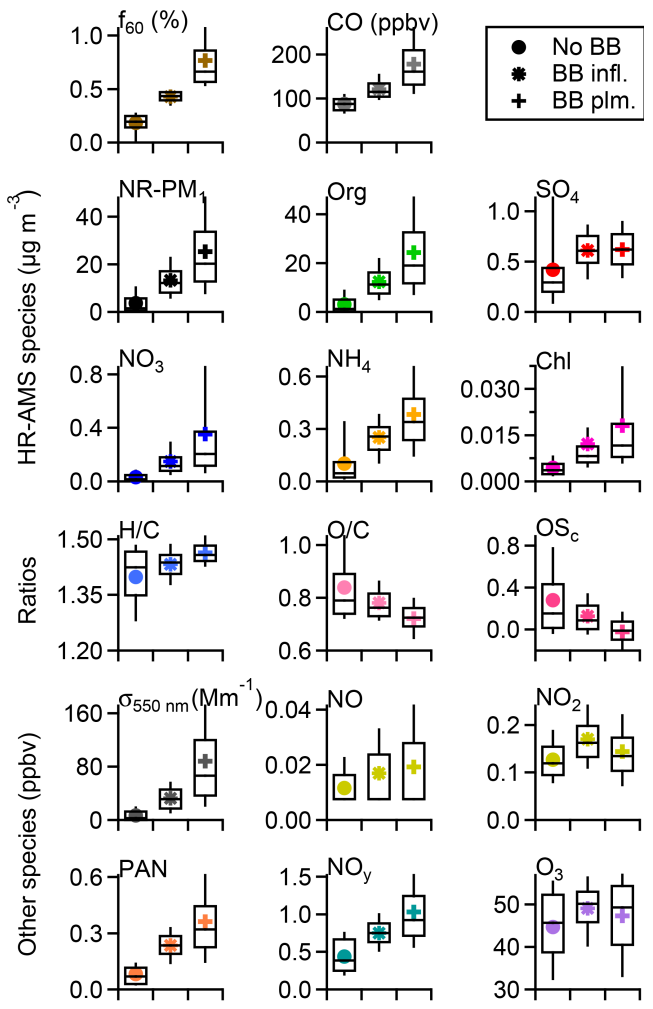

Figure 3. Box plots that compare $f_{60}$ values, $\mathrm{CO}$ mixing ratios, $\mathrm{NR}^{-\mathrm{PM}_{1}}$ species concentrations, OA elemental ratios, carbon oxidation states $\left(\mathrm{OS}_{c}\right), \sigma_{550 \mathrm{~nm}}$, and mixing ratios of trace gases among three aerosol regimes (No BB, BB Infl, and BB Plm). The whiskers indicate the 90th and 10th percentiles, the upper and lower boundaries respectively indicate the 75 th and 25 th percentiles, the lines in the boxes indicate the median values, and the markers indicate the mean values.

with wildfire impacts (Figs. 2-3, S8; Table S1). Nitrate, in particular, displayed large temporal variations that correlated with wildfire plume influences, and its concentration in the BB Plm regime was on average $\sim 11$ times greater than the No BB regime. Nitrate appeared to be bulk neutralized based on comparing the total molar equivalent of inorganic anions (i.e., sulfate, nitrate, and chloride) to that of ammonium (Zhang et al., 2005) during wildfire-influenced periods (Fig. S9a), and the signal ratios of $\mathrm{NO}^{+}$to $\mathrm{NO}_{2}^{+}$observed in particles during these periods $(2.15 \pm 0.006)$ were very similar to the ratio measured for pure $\mathrm{NH}_{4} \mathrm{NO}_{3}$ particles (2.2; Fig. S9b), indicating that nitrate was mostly in the form of $\mathrm{NH}_{4} \mathrm{NO}_{3}$. Note that for high-organic-loading $\left(>50 \mu \mathrm{g} \mathrm{m}^{-3}\right.$ ) periods excess ammonium relative to sulfate, nitrate, and chloride was frequently observed. A possible reason is the presence of significant amounts of organic anions in aerosol. Indeed, $\mathrm{CO}_{2}^{+}(\mathrm{m} / \mathrm{z}=44)$ and $\mathrm{CHO}_{2}^{+}(\mathrm{m} / \mathrm{z}=45)$ - ion fragments for carboxylic acids - were found to dominate the HRMS of aerosol during periods of high OA loading (Fig. S7f). Another possible reason is overestimation of 
ammonium concentration. Biomass burning can emit significant amounts of nitrogen-containing organic compounds, including amines. These compounds can produce $\mathrm{NH}_{x}^{+}$ions in the AMS, although they generally produce significantly more $\mathrm{C}_{x} \mathrm{H}_{y} \mathrm{~N}^{+}$ions (Ge et al., 2014). Tight correlations between $\mathrm{C}_{x} \mathrm{H}_{y} \mathrm{~N}^{+}$ions and biomass burning tracers (e.g., $\mathrm{CO}, \mathrm{C}_{2} \mathrm{H}_{4} \mathrm{O}_{2}^{+}$, and $\mathrm{C}_{3} \mathrm{H}_{5} \mathrm{O}_{2}^{+}$) were observed, suggesting that amino compounds were likely emitted from wildfires in the western US. However, the low abundance of $\mathrm{C}_{x} \mathrm{H}_{y} \mathrm{~N}^{+}$ ( $\sim 0.3 \%$ of total organic signal) indicates that organic nitrogen compounds unlikely had a noticeable influence on ammonium quantification during this study. Sulfate, on the other hand, displayed milder temporal variation with poor correlation with BB tracers (Fig. 2d-f), indicating that forest fires in this region are not a significant source of sulfate aerosol. Collier et al. (2016) came to a similar conclusion through examination of aerosol enhancement ratios in transported BB plumes.

Significant enhancements due to wildfires emissions were also observed for PAN and $\mathrm{NO}_{y}$ (Fig. 3). However, the mixing ratios of $\mathrm{NO}_{x}$ (mostly as $\mathrm{NO}_{2}$ ) were comparable among the three regimes. As a result, the fractional contributions of PAN and particulate nitrate to total $\mathrm{NO}_{y}$ both increased due to wildfire influence (Fig. S10). Considering that MBO was hours downwind of wildfire sources during this study, this observation is consistent with the findings of Akagi et al. (2012) that $\mathrm{NO}_{x}$ emitted from BB is rapidly converted to PAN and particulate nitrate during plume transport, which reflects high levels of acetaldehyde in fire plumes (Akagi et al., 2011). The influence of wildfire emissions on $\mathrm{O}_{3}$ at $\mathrm{MBO}$ appeared to be complex (Fig. 2c). The average $\mathrm{O}_{3}$ mixing ratio in both $\mathrm{BB}$ Infl (49.1 ppbv) and BB Plm (47.3 ppbv) regimes was higher than during the No BB (44.7 ppbv) periods (Fig. 3), suggesting that $\mathrm{O}_{3}$ production was enhanced in BB emissions. Similar observations have been made previously, which indicate that $\mathrm{O}_{3}$ tends to peak downwind of fire sources as a result of the interplay of fire emissions (precursors and reactants) and chemical reactions (Jaffe and Wigder, 2012; Wigder et al., 2013; Briggs et al., 2016).

\subsubsection{Influence of wildfires on organic aerosol chemical properties}

In order to demonstrate the influence of wildfires on bulk OA chemistry at MBO, the average HRMS of OA for each of the three regimes is shown in Fig. S7. OA was generally highly oxidized under all three regimes, and the $\mathrm{O} / \mathrm{C}$ of OA generally decreased as BB influence increased. In addition, ions larger than $100 \mathrm{amu}\left(f_{m / z>100}\right)$ contributed a larger fraction of the total organic signal during BB Plm periods $(11 \%)$ than during No BB periods $(5 \%)$, consistent with BBOA containing a larger fraction of high-molecular-weight compounds (Ge et al., 2012a; Lee et al., 2016). OA in No BB air masses had an average $\mathrm{O} / \mathrm{C}$ of $0.84\left(\mathrm{O} / \mathrm{C}_{\mathrm{AA}}\right.$; i.e., $\mathrm{O} / \mathrm{C}$ calculated with Aiken-Ambient method is 0.63 ) and $\mathrm{H} / \mathrm{C}$ of $1.48\left(\mathrm{H} / \mathrm{C}_{\mathrm{AA}}=1.29\right)$, in agreement with previous HRAMS measurements of free-tropospheric OA at mountaintop sites (e.g., Sun et al., 2009; Rinaldi et al., 2015). The average $\mathrm{O} / \mathrm{C}$ for $\mathrm{BB}$ Infl and $\mathrm{BB}$ Plm periods was 0.77 $\left(\mathrm{O} / \mathrm{C}_{\mathrm{AA}}=0.60\right)$ and $0.69\left(\mathrm{O} / \mathrm{C}_{\mathrm{AA}}=0.53\right)$, respectively, substantially higher than previously reported $\mathrm{O} / \mathrm{C}$ for fresh $\mathrm{BB}$ emissions. For example, laboratory experiments reported $\mathrm{O} / \mathrm{C}_{\mathrm{AA}}$ in the range of $0.15-0.60$ for POA from $\mathrm{BB}$, depending on fuel type, burning condition, and burn mass (Heringa et al., 2011; Ortega et al., 2013). The high O / C observed for $\mathrm{BB}$-influenced $\mathrm{OA}$ at $\mathrm{MBO}$ indicates that they were likely a combination of primary and secondary components, with the secondary portion having a substantial contribution to the bulk OA.

Changes in OA chemical composition due to wildfires is further investigated using the $f_{44}$ vs. $f_{60}$ plot (Fig. 4). All OA data showed a progression where lower $f_{60}$ values were associated with higher $f_{44}$, consistent with aging of BBOA observed both in laboratory studies and from airborne measurements (e.g., Cubison et al., 2011; Ortega et al., 2013; Jolleys et al., 2015). $f_{44}$ during No BB periods spanned the range of 0.13-0.25 (mean $=0.17$ ), due to the dominance of highly oxidized OA. BB Plm data fell within the region defined by the BBOA measured previously (Cubison et al., 2011; Ortega et al., 2013) and overlapped particularly well with fire plumes sampled above the North America continent during the 2008 NASA Arctic Research of the Composition of the Troposphere from Aircraft and Satellites (ARCTAS) mission and aged BBOA from controlled chamber open burning of biomass (Cubison et al., 2011). Ambient fire plumes tended to have higher $f_{44}$ and lower $f_{60}$ values than the POA from burning of various fuels in chamber studies (Ortega et al., 2013), mainly due to atmospheric aging. However, the mixing of transported BB smoke with more oxidized background aerosols likely also contributed to the changes in $f_{44}$ and $f_{60}$ observed for ambient BBOA. Furthermore, combustion conditions might also play a role in how plumes map to the $f_{44} \sim f_{60}$ space, as it has been shown in both ambient and chamber laboratory studies that flaming-dominated fires for certain fuel types can lead to higher $f_{44}$ and are associated with lower $f_{60}$ than more smouldering fires (Weimer et al., 2008; Jolleys et al., 2014; Collier et al., 2016).

\subsection{Aerosol source apportionment and contributions of primary and secondary BBOA at $\mathrm{MBO}$}

To gain further insight into the influences of different sources and processes on $\mathrm{OA}$ concentration and composition at MBO, we performed PMF analysis on the HRMS of all NR-PM ${ }_{1}$ species acquired during this study. PMF is commonly applied to the organic mass spectral matrix to determine distinct OA factors (Zhang et al., 2011, and references therein), but conducting PMF analysis on the combined spectra of organic and inorganic aerosols allows for deriving additional information, e.g., the distributions of inorganic signals 


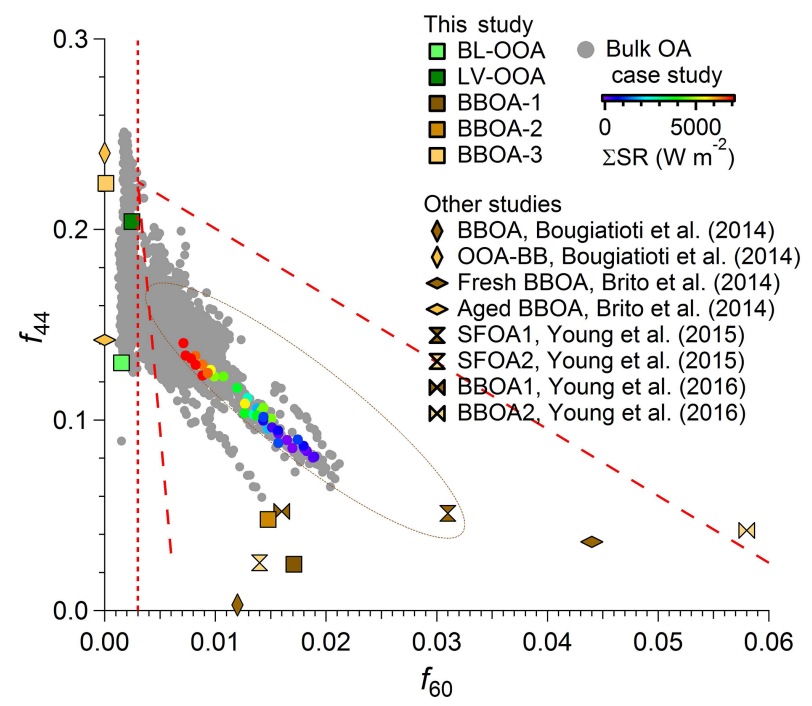

Figure 4. Scatterplot of $f_{44}$ vs. $f_{60}$. The grey markers correspond to the measured OA during this study, and the SRCF case study data are colored by cumulative solar radiation ( $\left.\sum \mathrm{SR}\right)$. In addition, the five OA factors identified in this study are shown as solid squares, and the BBOA factors reported in the literature where multiple BBOA factors were derived are shown with different markers. The dashed red lines denote $f_{60}=0.003$ and the boundaries set for BBOA (Ortega et al., 2013). The brown oval encompasses ARCTAS fire plumes sampled above the North America continent (Cubison et al., 2011).

among different factors and the nominal acidity of the factors, which benefits the interpretation of the sources, chemical characteristics, and evolution processes of OA (Sun et al., 2012). For this study, a total of five OA factors were identified, including three different BB-related aerosol types - i.e., BBOA-1 (O / C = 0.35), BBOA-2 (O / C = 0.60), and BBOA-3 $(\mathrm{O} / \mathrm{C}=1.06)$ - and two distinct OOA factors, i.e., a less oxidized OOA associated with boundary layer (BL) dynamics (BL-OOA, O / C = 0.69) and a more oxidized lowvolatility OOA representing free-troposphere aerosol (LVOOA, O / C = 1.09). Unlike the two OOAs, the three distinct BBOA factors all showed high correlations with $\mathrm{CO}$ $\left(r^{2}=0.70-0.86\right.$; Table S2) and displayed sporadic, highamplitude events with large enhancements in concentrations during wildfire-influenced periods (Fig. 5a-c). In addition, the polar plots of all the BBOAs showed clear concentration hotspots in the southwest direction at high wind speed (Fig. 6a-c), indicative of their associations with wildfire plumes originating from SW Oregon and NW California (Fig. 1). Nevertheless, the three BBOAs are distinctly different in terms of mass spectral profiles (Figs. 5k-m and S11), oxidation degrees, and volatility (Fig. 6g), likely due to different extents of aging and/or processing pathways. Similarly, previous studies reported the identification of multiple BBOA factors representative of different degree of atmospheric processing (e.g., Bougiatioti et al., 2014; Brito et al., 2014) and varying combustion conditions (e.g., Young et al., 2015, 2016). BBOA-1 and BBOA-2 looked more similar to the fresher BBOA factors, while BBOA-3 was more similar to the aged BBOA factors derived in Bougiatioti et al. (2014) and Brito et al. (2014) in terms of mass spectral features (Fig. 4).

Among the three BBOA factors, BBOA-1 had the lowest $\mathrm{O} / \mathrm{C}(0.35)$ and the highest $\mathrm{H} / \mathrm{C}$ (1.76) and $f_{60}$ $(2.2 \%)$ (Fig. 5k). In addition, the mass spectrum of BBOA-1 showed prominent signals of $\mathrm{C}_{2} \mathrm{H}_{3}^{+}, \mathrm{CHO}^{+}, \mathrm{C}_{4} \mathrm{H}_{7}^{+}, \mathrm{C}_{4} \mathrm{H}_{9}^{+}$, and $\mathrm{C}_{9} \mathrm{H}_{7}^{+}$, markers for chemically reduced aerosols, and a high abundance of ions larger than $100 \mathrm{amu}\left(f_{m / z>100}=\right.$ $25 \%$; Fig. $5 \mathrm{k}$ and $\mathrm{k}^{\prime}$ ). The UMR spectrum of BBOA-1 at $m / z>180$ exhibited a "picket fence" fragmentation pattern where groups of peaks have $14 \mathrm{amu}$ separation, suggesting the occurrence of molecules with hydrocarbon moieties containing different units of the $\mathrm{CH}_{2}$ group. The time series of BBOA-1 correlated tightly with those of $\mathrm{C}_{2} \mathrm{H}_{4} \mathrm{O}_{2}^{+}$and $\mathrm{C}_{4} \mathrm{H}_{9}^{+}$ $\left(r^{2}=0.94\right.$ and 0.95 , respectively; Table $\mathrm{S} 2$ ), tracers for primary emissions. Furthermore, BBOA-1 appeared to have a strong point source $\mathrm{SW}$ of $\mathrm{MBO}$ and peaked in association with high wind speeds, suggesting that it could be associated with plumes experiencing shorter transport times relative to plumes from equidistant fire sources (Fig. 6a). Together, these observations suggest that BBOA-1 was primarily associated with fresher and less processed air masses from BB sources. In addition, BBOA-1 was found to be semivolatile (Fig. 6g), which is consistent with previous findings that a majority (50-80\%) of the POA in BB emissions is semivolatile (May et al., 2013). The semivolatile behavior of BBOA-1 also explains the high degree of correlation between BBOA-1 and nitrate $\left(r^{2}=0.60\right.$; Fig. 5a and Table S2), a secondary species that is often found to correlate with semivolatile OOA (SV-OOA) (Zhang et al., 2011). However, despite being a secondary component, nitrate displayed tight correlations with primary smoke markers, i.e., $\mathrm{C}_{2} \mathrm{H}_{4} \mathrm{O}_{2}^{+}$and $\mathrm{C}_{3} \mathrm{H}_{5} \mathrm{O}_{2}^{+}$, at $\mathrm{MBO}$ (Fig. S12). Therefore, it appears that fast processing near the fire sources led to the rapid conversion of $\mathrm{NO}_{x}$ to more oxidized compounds such as PAN and nitrate. Based on these results, we infer that $\mathrm{BBOA}-1$ represents fresher $\mathrm{BB}$ emissions and might be a surrogate for primary BBOA. On average, BBOA-1 comprised $20 \%$ of total OA mass during this study (Fig. 6f), suggesting that fresh BB emissions exerted a significant impact on regional air masses.

The more oxygenated BBOA-2 $\quad(\mathrm{O} / \mathrm{C}=0.60$; $\mathrm{H} / \mathrm{C}=1.72$ ) accounted for an average $17 \%$ of the total OA mass (Fig. 6f). Its mass spectrum displayed characteristics of aged BBOA with lower abundances of $\mathrm{C}_{2} \mathrm{H}_{4} \mathrm{O}_{2}^{+}$ $\left(f_{60}=1.1 \%\right), \mathrm{C}_{x} \mathrm{H}_{y}^{+}$ions $(31 \%)$, and ions $>100 \mathrm{amu}$ $\left(f_{m / z>100}=17 \%\right)$ than BBOA-1 (Figs. 4l, $\mathrm{l}^{\prime}$ and S9b). BBOA-2 also showed a somewhat less volatile profile than BBOA-1, especially at TD temperature $<150{ }^{\circ} \mathrm{C}$ (Fig. $6 \mathrm{~g}$ ). In addition, the temporal trend of BBOA-2 displayed tight correlations with tracers for carboxylic acids, e.g., $\mathrm{CHO}_{2}^{+}$ 

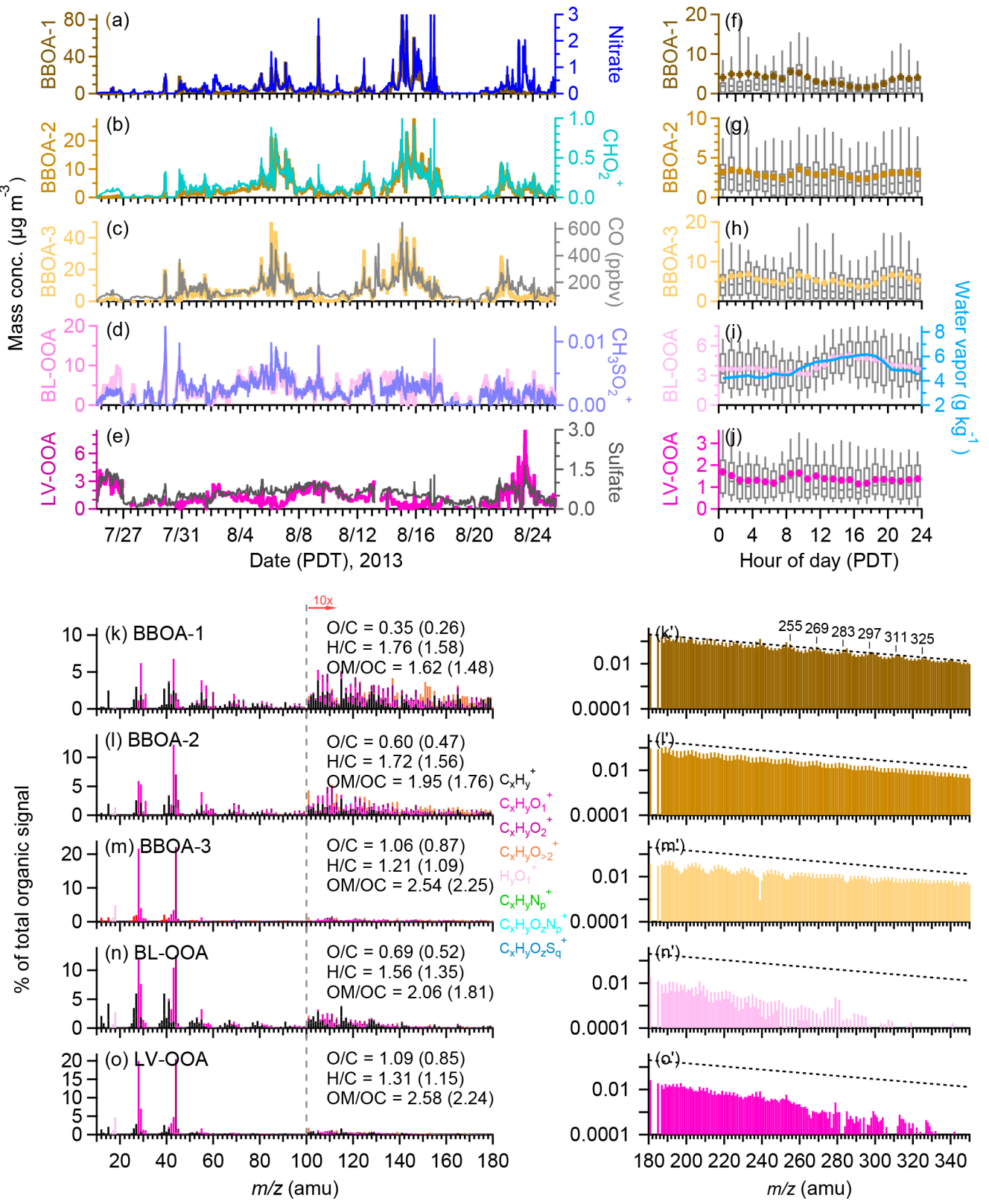

Figure 5. (a-e) Time series of OA factors and corresponding tracer compounds. Organic ions are in organic equivalent mass; (f-g) diurnal variations of OA factors (the whiskers above and below the boxes indicate the 90th and 10th percentiles, the upper and lower boundaries respectively indicate the 75 th and 25 th percentiles, the lines in the boxes indicate the median values, and the cross symbols indicate the mean values) with the diurnal cycle of mean water vapor in panel (i); (k-o) HRMS of OA factors colored by eight ion families at $m / z<180$, and $\left(\mathbf{k}^{\prime}-\mathbf{o}^{\prime}\right)$ UMR MS at $m / z>180$ for each OA factor. The elemental ratios of each OA factor are shown in the legends of panels (k-o), with those obtained using the AA method in parenthesis.

and $\mathrm{CO}_{2}^{+}\left(r^{2}\right.$ of 0.91 and 0.79 , respectively; Fig. $5 \mathrm{~b}$ and Table S2), but lower correlations with nitrate, $\mathrm{C}_{2} \mathrm{H}_{4} \mathrm{O}_{2}^{+}$, and $\mathrm{C}_{4} \mathrm{H}_{9}^{+}$. These results suggest that BBOA-2 was more chemically processed and likely contained secondary products. Indeed, the polar plot of BBOA-2 (Fig. 6b) displayed a more dispersed pattern of sources than that of BBOA-1, with hotspots located in various directions. Nevertheless, the occurrence of a high-concentration band at $5-15 \mathrm{~m} \mathrm{~s}^{-1}$ in the SW direction suggests important BBOA-2 sources from similar distances and locations to BBOA-1. The dispersed source features are further evidence that BBOA-2 is more secondary in nature than BBOA-1 and is likely more aged.

BBOA-3 contrasts strongly with BBOA- 1 and BBOA-2 in chemical composition. The HRMS of BBOA-3 had a very 


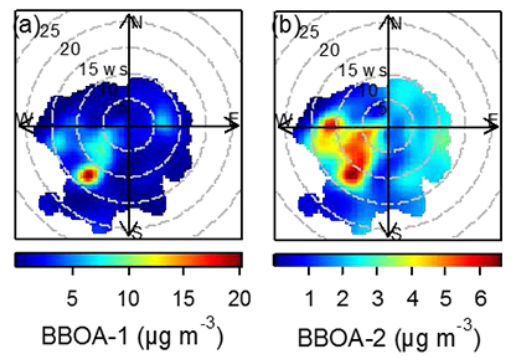

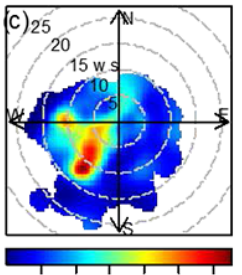

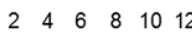

BBOA-3 $\left(\mu \mathrm{g} \mathrm{m}^{-3}\right)$
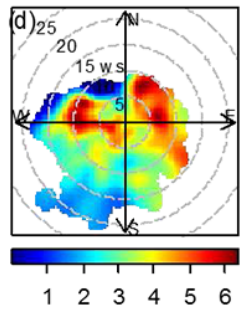

$\mathrm{BL}-\mathrm{OOA}\left(\mu \mathrm{g} \mathrm{m}^{-3}\right)$

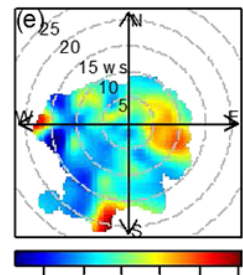

$\begin{array}{lllll}0.5 & 1 & 1.5 & 2 & 2.5\end{array}$

LV-OOA $\left(\mu \mathrm{g} \mathrm{m}^{-3}\right)$

(f) Average OA composition
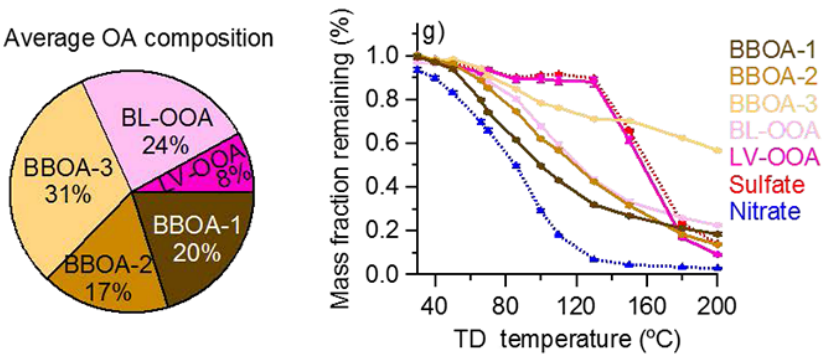

Figure 6. (a-e) Bivariate polar plots that illustrate the variations of the concentrations of each OA factor as a function of wind speed (m $\mathrm{s}^{-1}$ ) and wind direction; (f) average OA composition during the sampling period; and (g) volatility profiles of OA factors, sulfate, and nitrate, with error bars showing the standard deviation of the calculated slope, i.e., mass fraction remaining.

low $\mathrm{C}_{2} \mathrm{H}_{4} \mathrm{O}_{2}^{+}$signal $\left(f_{60}=4 \times 10^{-8}\right)$, a relatively high intensity of $\mathrm{CO}_{2}^{+}\left(f_{44}=0.215\right)$ and a high degree of oxidation $(\mathrm{O} / \mathrm{C}=1.07$; Fig. $5 \mathrm{~m})$, all of which greatly resemble those of LV-OOA (Fig. 5o). However, the mass spectra at large $m / z$ 's indicated distinct chemical differences between BBOA-3 and LV-OOA (Fig. $5 \mathrm{~m}^{\prime}$ and $\mathrm{o}^{\prime}$ ), as there appeared to be a higher abundance of high-molecular-weight species in BBOA-3. In addition, the temporal variation patterns of BBOA-3 and LV-OOA were dramatically different $\left(r^{2}=0.07\right)$, and BBOA-3 closely correlated with $\mathrm{CO}$ $\left(r^{2}=0.86\right.$; Fig. $5 \mathrm{c}$ and Table S2), whereas LV-OOA did not $\left(r^{2}=0.008\right)$. As shown in Fig. 6, the polar plot of BBOA-3 showed a high-concentration band from SW at a wind speed of $5-15 \mathrm{~m} \mathrm{~s}^{-1}$, which overlaps with the hot spot shown in the BBOA-1 polar plot (Fig. 6a). These results indicate that BBOA-3 was associated with wildfires and likely formed both through rapid processing near the wildfire source and during transport to MBO. However, given that humic-like substances (HULIS) are a known component of BB emissions and that these substances resemble BBOA-3 in terms of AMS mass spectrum, high degree of oxygenation, and low volatility (Dinar et al., 2006; Adler et al., 2011), it is possible that a fraction of BBOA-3 was HULIS as well.

Another important characteristic of BBOA-3 is that it appeared to be composed of some very low volatility compounds. As shown in Fig. $6 \mathrm{~g}, \sim 60 \%$ of its mass remained in the aerosol phase at a temperature of $200^{\circ} \mathrm{C}$. This observation is consistent with previous studies which have observed the presence of low-volatility and extremely low volatility BBOA materials in aged wildfire plumes (Lee et al., 2016; Paciga et al., 2016) and in SOA produced from major organic gases from BB (e.g., phenols) (Yu et al., 2016). It is important to note that the highly oxidized BBOA-3 on average accounted for $31 \%$ of the total OA mass during this study, which implies that a significant fraction of the highly aged BBOA may appear indistinguishable from OOA from other sources due to mass spectral similarities (e.g., low $f_{60}$ and high $f_{44}$ ) and hence would lead to an underestimation of the influence of $\mathrm{BB}$ emissions on a regional scale.

BL-OOA and LV-OOA accounted for the remaining $32 \%$ of total OA mass during this study. These two OOAs were not associated with BB, as indicated by low $f_{60}$ (Fig. $5 \mathrm{n}$ and o) and a lack of correlation with BB tracers (Table S2). BLOOA was relatively oxidized $(\mathrm{O} / \mathrm{C}=0.69$; Fig. $5 \mathrm{n})$ and appeared significantly less volatile than nitrate but more volatile than sulfate (Fig. 6g). BL-OOA showed a distinct diurnal cycle highly resembling that of water vapor (Fig. 5i), which is a tracer for BL upslope flow during the daytime at MBO (Weiss-Penzias et al., 2006). Photochemical production of $\mathrm{OA}$ in the early afternoon may also contribute to the daytime increase of BL-OOA. Furthermore, the time series of BL-OOA correlated with $\mathrm{CH}_{3} \mathrm{SO}_{2}^{+}$(Fig. 5d and Table S2), a signature ion for methanesulfonic acid (MSA) (Ge et al., 2012b). MSA is typically associated with marine sources but has been found to have terrestrial sources as well (Ge et al., 2012b; Young et al., 2016). All these results suggest the influence of BL dynamics on BL-OOA. In comparison, the LVOOA was highly oxidized $(\mathrm{O} / \mathrm{C}=1.09)$ with a pronounced $\mathrm{CO}_{2}^{+}$peak in the spectrum (Fig. 5o). In addition, Fig. 6g indicates that LV-OOA shared a similar volatility profile to sulfate, showing no sign of evaporation until the TD temperature reached nearly $130^{\circ} \mathrm{C}$, consistent with LV-OOA previously determined in other ambient studies (Huffman et al., 2009; Paciga et al., 2016). The diurnal pattern of LV-OOA 
$\diamond$ MODIS fire dots
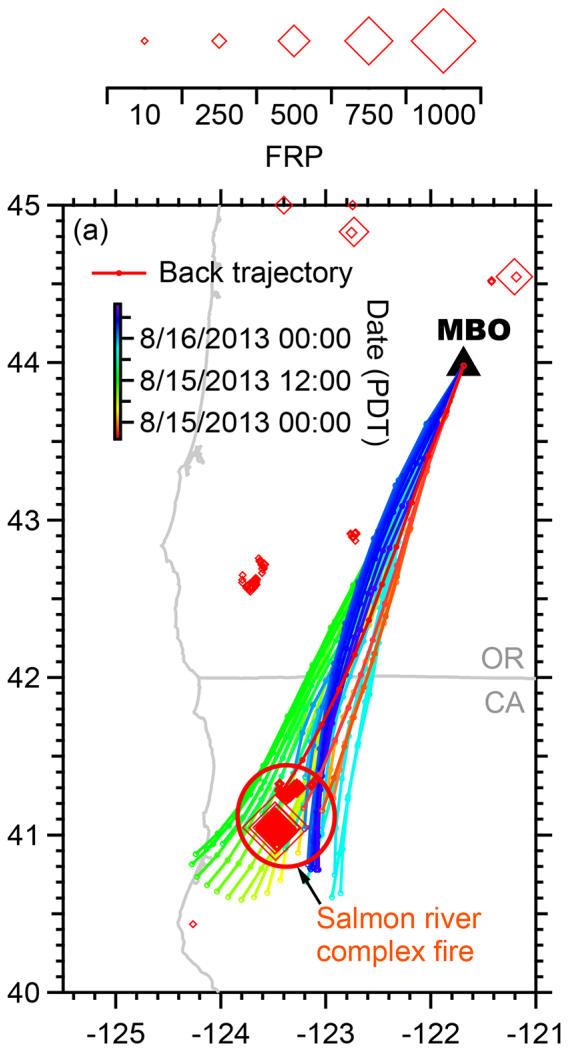

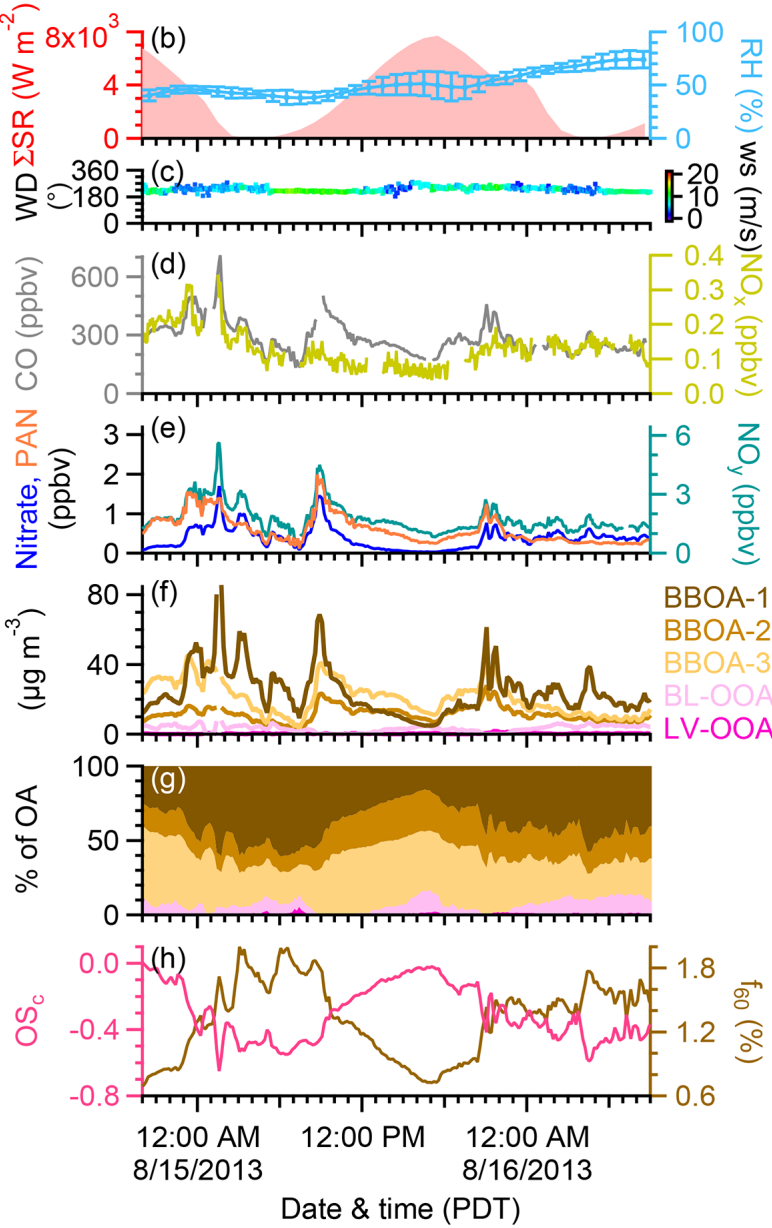

Figure 7. (a) Map of the Pacific Northwest with the location of MBO marked by a black triangle. Open diamonds represent MODIS satellite fire dots detected during 13-17 August 2013 and are sized by fire radiative power (FRP). Twelve-hour HYSPLIT back trajectories of air masses arriving at MBO from 14 August at 20:00 to 16 August at 09:00 PDT are colored by time of arrival at MBO. Markers indicate 1 $\mathrm{h}$ interval; (b) cumulative solar radiation ( $\sum \mathrm{SR}$ ) and average RH for each trajectory; (c) wind direction (WD) colored by wind speed (WS) measured at $\mathrm{MBO}$; mixing ratios of (d) $\mathrm{CO}$ and $\mathrm{NO}_{x}$; mixing ratios of (e) nitrate, $\mathrm{PAN}$, and $\mathrm{NO}_{y}$; (f) five OA factors; (g) OA composition; and (h) average carbon oxidation states and $f_{60}$ of OA during the SRCF case study period.

appeared to be rather flat (Fig. 5j), and its polar plot had the most dispersed feature among all factors (Fig. 6e). All these observations suggest that this factor is representative of freetropospheric aerosol.

\subsection{A case study of the aging of $\mathrm{BBOA}$ in wildfire plumes}

Based on MODIS fire hotspot information, the SRCF was continuously burning from 13 to 17 August (Fig. 7a). Threeday HYSPLIT back trajectories suggest that air masses arriving at MBO from 14 August at 22:00 to 16 August at 09:00 PDT passed over the SRCF (Fig. 7a), consistent with the observations of persistent $\mathrm{SW}$ wind at $\mathrm{MBO}$ during this period (Fig. 7c). MODIS also detected a few hotspots from the Whiskey Complex fire $\left(\sim 43^{\circ} \mathrm{N}, 122.8^{\circ} \mathrm{W}\right)$ intermittently on August 15, but the fire was much weaker than SRCF as indicated by the lower fire radiative power (FRP, Fig. 7a). We therefore assume that the emissions arriving at MBO during this time period were from a single source and therefore consistent in transport distance and fuel type. Combining MODIS fire hotspots and back trajectories, we estimated that the transport time of SRCF plumes ranged from 8 to $11 \mathrm{~h}$ before being sampled at MBO.

In order to examine how atmospheric aging affects BBOA chemistry, we calculated cumulative solar radiation $\left(\sum \mathrm{SR}\right)$ and average $\mathrm{RH}$ over the total transport time (from source to MBO) for each trajectory and plotted them versus air mass arrival time in Fig. 7b. $\sum$ SR denotes the total amount of solar radiation that the smoke plumes were exposed to during transport and can be used as an indicator for the extent of photochemical aging assuming the plumes were optically thin. RH in the air mass history was relatively stable; how- 
ever $\sum$ SR clearly varied throughout the measurement period such that some BB plumes experienced more solar radiation than others and some were transported exclusively at night. Furthermore, the burn conditions were modestly constant during this period with an average modified combustion efficiency (MCE) value of $0.88( \pm 0.03)$ for the BB plumes that met the criteria for MCE calculation (Collier et al., 2016). Furthermore, the MCE values showed no differences between nighttime and daytime plumes and did not correlate with $\sum$ SR (Fig. S13). These conditions, together with the high emission concentrations for both gas and particle phase components (Fig. 7d-f), provide a near-ideal case study where atmospheric aging is likely the largest factor affecting the chemical evolution of BBOA.

During this $\mathrm{SRCF}$ case study period, $\mathrm{CO}, \mathrm{NO}_{y}$, and PAN mixing ratios observed at $\mathrm{MBO}$ exhibited similar trends that varied dynamically and correlated well with the fresh BBOA1 factor (Fig. $7 \mathrm{~d}-\mathrm{f}$ ). In addition, OA was overwhelmingly dominated by BBOAs, which summed to contribute 80 $99 \%$ of total OA mass (Fig. 7g). The chemical parameters of OA and the fractional contributions of each BBOA factor appear to be related to $\sum \mathrm{SR}$ (Fig. $6 \mathrm{~g}$ and $\mathrm{h}$ ). In order to investigate the chemical evolution of BBOA, we reconstructed the time series and the chemistry parameters of total BBOA (= BBOA-1 + BBOA-2 + BBOA-3) from the residual matrix of organic aerosol after subtracting the contributions from BL-OOA and LV-OOA. The carbon oxidation state $\left(\mathrm{OS}_{\mathrm{c}}=2 \times \mathrm{O} / \mathrm{C}-\mathrm{H} / \mathrm{C}\right.$; Kroll et al., 2011) of total BBOA showed a clear increasing trend with respect to $\sum \mathrm{SR}$, consistent with the trends of $\mathrm{O} / \mathrm{C}$ and $f_{44}$, while $\mathrm{H} / \mathrm{C}, f_{60}$, and $f_{m / z}>100$ of total BBOA showed decreasing trends with $\sum$ SR (Fig. 8). The relationship between $f_{44}$ and $f_{60}$ for total OA observed during this case study is shown in Fig. 4. $f_{60}$ decreased with increased $f_{44}$ due to aging, and the data overlapped with the aged BBOA from controlled chamber open burning of turkey oak (Cubison et al., 2011). These results suggest oxidation of anhydrous sugar and other BBOA components due to photochemical aging, consistent with previous observations in the laboratory (Grieshop et al., 2009; Hennigan et al., 2011; Ortega et al., 2013) and field (Cubison et al., 2011; May et al., 2015). In addition, the negative correlation between BBOA-1 and $\sum$ SR and the positive correlations of BBOA-2 and BBOA-3 with $\sum$ SR (Fig. 8) corroborated our earlier assumption that BBOA-2 and BBOA-3 represented more aged, secondary BBOA whereas BBOA-1 represented primary BBOA.

We classify the plumes according to $\sum S R$ and designate those as nighttime transported if $\sum$ SR was below $500 \mathrm{~W} \mathrm{~m}^{-2}$, and we classify the rest as daytime transported. $\mathrm{OA}$ concentration and $\mathrm{CO}$ mixing ratio were tightly correlated, with $r^{2}=0.88$ and 0.94 for nighttime- and daytimetransported plumes, respectively (Fig. 9a). CO has been commonly used as a stable plume tracer to account for dilution, and the slope obtained from orthogonal fitting between $\mathrm{OA}$ and $\mathrm{CO}$ is defined as the enhancement ratio (i.e.,

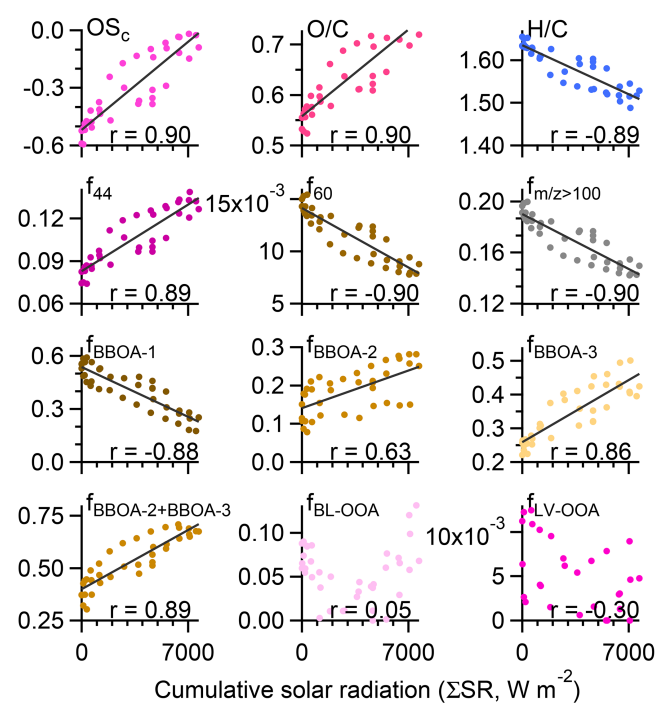

Figure 8. Aerosol chemistry parameters of total BBOA as a function of cumulative solar radiation for the Salmon River Complex fire case study. The Pearson's correlation coefficients $(r)$ are reported.

$\Delta \mathrm{OA} / \Delta \mathrm{CO})$. Change of $\Delta \mathrm{OA} / \Delta \mathrm{CO}$ during plume transport indicates the influence of factors other than dilution, e.g., SOA formation or OA evaporation. For the SRCF case study, $\triangle \mathrm{OA} / \triangle \mathrm{CO}$ was very similar for the day plumes and the night plumes: $0.28 \pm 0.014$ vs. $0.27 \pm 0.005 \mu \mathrm{g} \mathrm{m}^{-3} \mathrm{ppbv}^{-1}$ respectively (Fig. 9a), suggesting no net OA mass enhancement due to photochemical aging. This is consistent with the findings of Collier et al. (2016), which compared selected BB events from this dataset measured at MBO to those aboard a research aircraft sampling fresher plume emissions and found very similar OA enhancements between the fresher and more aged emissions. However, compared to daytime plumes, OA for plumes transported during nighttime was less oxidized (Fig. 9c and d) and was dominated by the fresh BBOA-1 (53\%), followed by the most oxidized BBOA-3 (24\%) and intermediately oxidized BBOA-2 (15\%; Fig. 9b). By contrast, daytime plumes were characterized by a significant decrease in the mass fraction of BBOA-1 (37\%) coupled with increases in the fractions of BBOA-2 $(20 \%)$ and BBOA-3 (37\%). This is corroborated by the significant differences in chemical composition for the two types of plumes, where the average HRMS (Fig. 9c and d) indicated that the BBOA in daytime plumes had a higher degree of oxidation (average $\mathrm{O} / \mathrm{C}=0.66$ ) than the night plumes $(\mathrm{O} / \mathrm{C}=0.55)$. These observations together suggest that, although net OA production was conserved with higher photochemical aging, BBOA was chemically transformed, likely due to oxidative processing in both gas and particles phases followed by fragmentation and volatilization. 

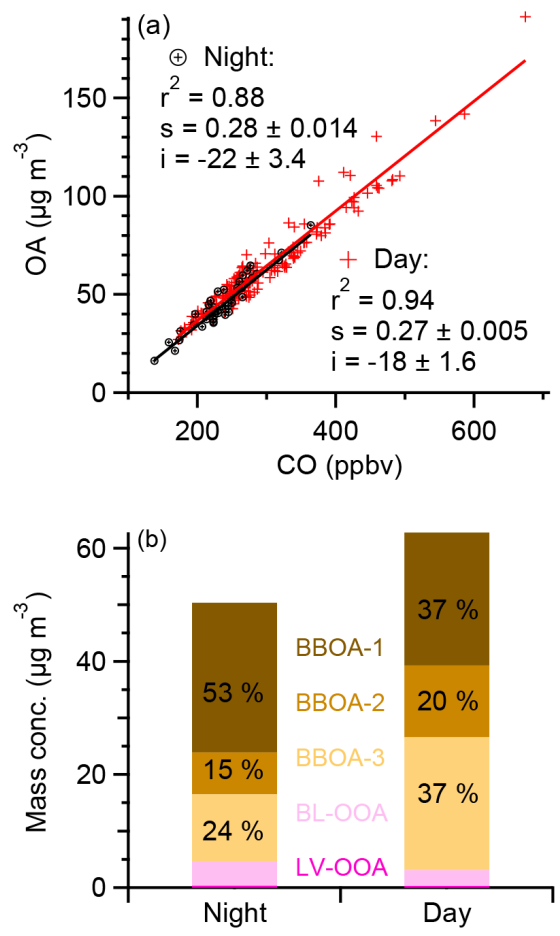
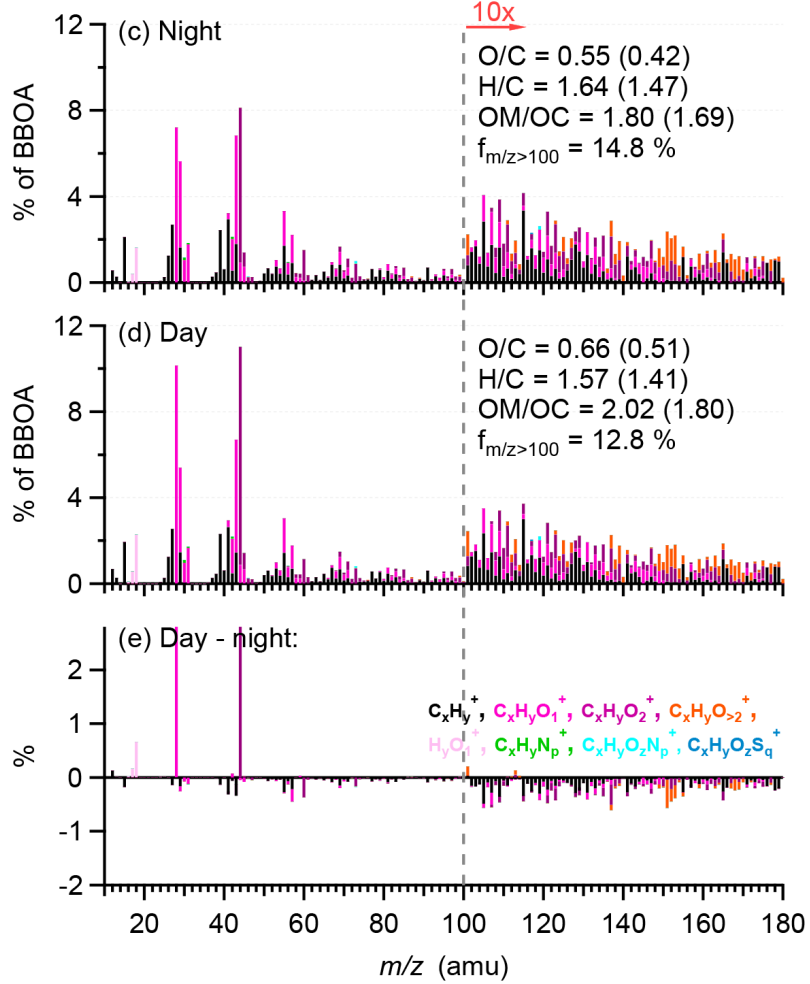

Figure 9. (a) OA vs. CO during 14 August at 20:00 to 16 August at 09:00 PDT with nighttime-transported plumes illustrated as black circles and daytime-transported plumes as red crosses. The orthogonal distance regression (ODR) results for the two plume types are shown with the $1 \sigma$ uncertainties reported for the fit slopes $(s)$ and intercepts $(i)$; (b) a comparison of the average concentrations of five OA factors (stacked) between the nighttime- and daytime-transported plumes. The average mass fractions of the BBOAs to total OA mass in each plume type are reported; (c) average HRMS of total BBOA for the nighttime-transported plumes; (d) average HRMS of total BBOA for the daytimetransported plumes; and (e) difference BBOA HRMS between day and night plumes. The elemental ratios of BBOA calculated with the IA method are shown in the legends of panels (c) and (d), with those obtained using the AA method in parenthesis.

\section{Summary and conclusions}

We have characterized the chemical composition and properties of aerosols at a high-elevation site that was heavily impacted by wildfire smoke plumes in the western US during the BBOP campaign in summer 2013. The sampling site was located on the summit of Mt. Bachelor, an isolated volcanic peak in central Oregon. It was impacted by regional wildfire emission during a majority of the campaign and saw intense BB plumes with elevated air pollutants (up to $700 \mathrm{ppbv}$ of $\mathrm{CO}$ and $\sim 210 \mu \mathrm{g} \mathrm{m}^{-3}$ of NR-PM 1$)$. The average $( \pm 1 \sigma)$ NR-PM 1 mass concentration was $22.4( \pm 17.7) \mu \mathrm{g} \mathrm{m}^{-3}$ during fire-impacted periods, mostly due to OA that dominated the NR-PM 1 composition. In contrast, the average NR-PM concentration was only $3.7 \mu \mathrm{g} \mathrm{m}^{-3}$ over periods free of BB influence, and the aerosols contained a high mass fraction of ammonium sulfate (up to $\sim 90 \%$ ). In addition to increasing regional aerosol concentrations, wildfires in the Pacific Northwest region also significantly increased the mixing ratios of $\mathrm{CO}, \mathrm{NO}_{y}$, and $\mathrm{PAN}$, although $\mathrm{NO}_{x}$ and $\mathrm{O}_{3}$ displayed more complex behavior.
PMF analysis identified three types of BBOA that together accounted for $68 \%$ of the OA mass during this study, in addition to two types of OOA representing regional air conditions. The time series of all BBOA factors displayed dynamic variations that tightly correlated with those of $\mathrm{CO}$ and aerosol light scattering. Yet the three BBOAs were significantly different both chemically and physically and appeared to have been subjected to different degrees of atmospheric processing. BBOA-1 appeared to represent fresh wildfire emissions and featured semivolatile behavior, low $\mathrm{O} / \mathrm{C}$, a larger fraction of anhydrous sugar $\left(f_{60}=2.2 \%\right)$, and a strong association with active wildfire sources. On the other hand, BBOA-2 and BBOA-3 represented more aged BB emissions and showed higher oxidation degree, lower $f_{60}$, significantly lower volatilities, and more dispersed source regions. BBOA3 , in particular, had an $\mathrm{O} / \mathrm{C}$ of 1.06 , very low volatility, and almost no contribution from $f_{60}$, and it thus appeared to be chemically similar to highly oxidized SOA observed in the atmosphere. Nevertheless, BBOA-3 is substantially different than the LV-OOA factor identified in this study; in addition to dramatically different temporal variation patterns, BBOA- 
3 also seemed to be composed of a higher fraction of highmolecular-weight species as well as compounds of extremely low volatilities.

A case study using consecutive BB plumes transported from the same fire source was performed to examine in detail the environmental factors leading to BBOA evolution. The BB plumes were associated with fires of similar modified combustion efficiencies but were exposed to a wide range of photochemical aging, as indicated by the cumulative solar radiation along the trajectory history from fire source to the sampling site. The results showed that photochemical aging led to more oxidized OA with higher mass fractions of aged BBOA (i.e., BBOA-2 and BBOA-3) and a lower fraction of fresh BBOA-1. Although BBOA in daytime plumes were chemically more processed than nighttime plumes, the enhancement ratios of OA relative to $\mathrm{CO}$ were very similar under the nighttime and daytime conditions $(\triangle \mathrm{OA} / \Delta \mathrm{CO}=0.28 \pm 0.014$ and $0.27 \pm 0.005 \mathrm{\mu g} \mathrm{m}^{-3} \mathrm{ppbv}^{-1}$, respectively). One explanation for this apparent lack of net SOA production in transported $\mathrm{BB}$ plumes is that SOA formation in $\mathrm{BB}$ emissions was balanced by POA loss, likely due to oxidation followed by fragmentation and volatilization.

Over the entire period of this study, the aged BBOA-2 and BBOA-3, most of which were likely secondary, on average made up $\sim 50 \%$ of the OA mass observed at MBO. Aged BBOAs were present at significant concentrations even in relatively fresh plumes ( $\sim 6-12 \mathrm{~h}$ of atmospheric aging). These results suggest that BB emissions undergo substantial chemical processing which commences immediately after emission and continues during atmospheric transport, forming and transforming aerosols that can significantly influence air quality and atmospheric chemical composition at downwind sites with important implications for health and climate.

\section{Data availability}

Data presented in this manuscript are available upon request to the corresponding author.

\section{The Supplement related to this article is available online at doi:10.5194/acp-17-2477-2017-supplement.}

Competing interests. The authors declare that they have no conflict of interest.

Acknowledgements. This work was funded by the US Department of Energy (DOE) Office of Science, Office of Biological and Environmental Research Atmospheric System Research (ASR) program DE-SC0014620 and DE-SC0007178. Shan Zhou was partially funded by a $\mathrm{PhD}$ grant from the Chinese Scholarship Council (CSC) and the Donald G. Crosby Fellowship at UC Davis. We acknowledge the use of MODIS fire hotspot data and imagery from the Land, Atmosphere Near real-time Capability for EOS (LANCE) Fire Information for Resource Management System (FIRMS), downloadable from https://firms.modaps.eosdis.nasa.gov and operated by the NASA Goddard Space Flight Center (GSFC) Earth Science Data and Information System (ESDIS) with funding provided by NASA HQ. Special acknowledgement goes to Mt. Bachelor summit ski lift technicians; Advanced Northwest Welding, LLC; and our lab members - Caroline Parworth, Xinlei $\mathrm{Ge}$, and Jianzhong $\mathrm{Xu}$ - whose help was invaluable in setting up logistics for site sampling. MBO is supported by a grant to the University of Washington from NSF (NSF\# 1447832).

Edited by: N. L. Ng

Reviewed by: two anonymous referees

\section{References}

Abel, S. J., Haywood, J. M., Highwood, E. J., Li, J., and Buseck, P. R.: Evolution of biomass burning aerosol properties from an agricultural fire in southern Africa, Geophys. Res. Lett., 30, 1783, doi:10.1029/2003GL017342, 2003.

Adler, G., Flores, J. M., Abo Riziq, A., Borrmann, S., and Rudich, Y.: Chemical, physical, and optical evolution of biomass burning aerosols: a case study, Atmos. Chem. Phys., 11, 1491-1503, doi:10.5194/acp-11-1491-2011, 2011.

Aiken, A. C., Decarlo, P. F., Kroll, J. H., Worsnop, D. R., Huffman, J. A., Docherty, K. S., Ulbrich, I. M., Mohr, C., Kimmel, J. R., Sueper, D., Sun, Y., Zhang, Q., Trimborn, A., Northway, M., Ziemann, P. J., Canagaratna, M. R., Onasch, T. B., Alfarra, M. R., Prevot, A. S. H., Dommen, J., Duplissy, J., Metzger, A., Baltensperger, U., and Jimenez, J. L.: O / C and OM / OC ratios of primary, secondary, and ambient organic aerosols with highresolution time-of-flight aerosol mass spectrometry, Environ. Sci. Technol., 42, 4478-4485, doi:10.1021/es703009q, 2008.

Akagi, S. K., Yokelson, R. J., Wiedinmyer, C., Alvarado, M. J., Reid, J. S., Karl, T., Crounse, J. D., and Wennberg, P. O.: Emission factors for open and domestic biomass burning for use in atmospheric models, Atmos. Chem. Phys., 11, 4039-4072, doi:10.5194/acp-11-4039-2011, 2011.

Akagi, S. K., Craven, J. S., Taylor, J. W., McMeeking, G. R., Yokelson, R. J., Burling, I. R., Urbanski, S. P., Wold, C. E., Seinfeld, J. H., Coe, H., Alvarado, M. J., and Weise, D. R.: Evolution of trace gases and particles emitted by a chaparral fire in California, Atmos. Chem. Phys., 12, 1397-1421, doi:10.5194/acp-12-13972012, 2012.

Alfarra, M. R., Prevot, A. S. H., Szidat, S., Sandradewi, J., Weimer, S., Lanz, V. A., Schreiber, D., Mohr, M., and Baltensperger, U.: Identification of the Mass Spectral Signature of Organic Aerosols from Wood Burning Emissions, Environ. Sci. Technol., 41, 5770-5777, doi:10.1021/es062289b, 2007.

Allan, J. D., Delia, A. E., Coe, H., Bower, K. N., Alfarra, M. R., Jimenez, J. L., Middlebrook, A. M., Drewnick, F., Onasch, T. B., Canagaratna, M. R., Jayne, J. T., and Worsnop, D. R.: A generalised method for the extraction of chemically resolved mass 
spectra from aerodyne aerosol mass spectrometer data, J. Aerosol Sci., 35, 909-922, doi:10.1016/j.jaerosci.2004.02.007, 2004.

Artaxo, P., Rizzo, L. V., Brito, J. F., Barbosa, H. M. J., Arana, A., Sena, E. T., Cirino, G. G., Bastos, W., Martin, S. T., and Andreae, M. O.: Atmospheric aerosols in Amazonia and land use change: from natural biogenic to biomass burning conditions, Faraday Discuss., 165, 203-235, doi:10.1039/c3fd00052d, 2013.

Bond, T. C., Streets, D. G., Yarber, K. F., Nelson, S. M., Woo, J.-H., and Klimont, Z.: A technology-based global inventory of black and organic carbon emissions from combustion, J. Geophys. Res.-Atmos., 109, D14203, doi:10.1029/2003JD003697, 2004.

Bougiatioti, A., Stavroulas, I., Kostenidou, E., Zarmpas, P., Theodosi, C., Kouvarakis, G., Canonaco, F., Prévôt, A. S. H., Nenes, A., Pandis, S. N., and Mihalopoulos, N.: Processing of biomassburning aerosol in the eastern Mediterranean during summertime, Atmos. Chem. Phys., 14, 4793-4807, doi:10.5194/acp-144793-2014, 2014.

Briggs, N. L., Jaffe, D. A., Gao, H., Hee, J. R., Baylon, P. M., Zhang, Q., Zhou, S., Collier, S. C., Sampson, P. D., and Cary, R. A.: Particulate Matter, Ozone, and Nitrogen Species in Aged Wildfire Plumes Observed at the Mount Bachelor Observatory, Aerosol Air Qual. Res., 16, 3075-3087, doi:10.4209/aaqr.2016.03.0120, 2016.

Brito, J., Rizzo, L. V., Morgan, W. T., Coe, H., Johnson, B., Haywood, J., Longo, K., Freitas, S., Andreae, M. O., and Artaxo, P.: Ground-based aerosol characterization during the South American Biomass Burning Analysis (SAMBBA) field experiment, Atmos. Chem. Phys., 14, 12069-12083, doi:10.5194/acp-1412069-2014, 2014.

Canagaratna, M. R., Jimenez, J. L., Kroll, J. H., Chen, Q., Kessler, S. H., Massoli, P., Hildebrandt Ruiz, L., Fortner, E., Williams, L. R., Wilson, K. R., Surratt, J. D., Donahue, N. M., Jayne, J. T., and Worsnop, D. R.: Elemental ratio measurements of organic compounds using aerosol mass spectrometry: characterization, improved calibration, and implications, Atmos. Chem. Phys., 15, 253-272, doi:10.5194/acp-15-253-2015, 2015.

Capes, G., Johnson, B., McFiggans, G., Williams, P. I., Haywood, J., and Coe, H.: Aging of biomass burning aerosols over West Africa: Aircraft measurements of chemical composition, microphysical properties, and emission ratios, J. Geophys. Res.Atmos., 113, D00C15, doi:10.1029/2008JD009845, 2008.

Carslaw, D. C. and Ropkins, K.: openair - An R package for air quality data analysis, Environ. Modell. Softw., 27-28, 52-61, doi:10.1016/j.envsoft.2011.09.008, 2012.

Collier, S. and Zhang, Q.: Gas-Phase $\mathrm{CO}_{2}$ Subtraction for Improved Measurements of the Organic Aerosol Mass Concentration and Oxidation Degree by an Aerosol Mass Spectrometer, Environ. Sci. Technol., 47, 14324-14331, doi:10.1021/es404024h, 2013.

Collier, S., Zhou, S., Onasch, T. B., Jaffe, D. A., Kleinman, L., Sedlacek, A. J., Briggs, N. L., Hee, J., Fortner, E., Shilling, J. E., Worsnop, D., Yokelson, R. J., Parworth, C., Ge, X., Xu, J., Butterfield, Z., Chand, D., Dubey, M. K., Pekour, M. S., Springston, S., and Zhang, Q.: Regional Influence of Aerosol Emissions from Wildfires Driven by Combustion Efficiency: Insights from the BBOP Campaign, Environ. Sci. Technol., 50, 8613-8622, doi:10.1021/acs.est.6b01617, 2016.

Cubison, M. J., Ortega, A. M., Hayes, P. L., Farmer, D. K., Day, D., Lechner, M. J., Brune, W. H., Apel, E., Diskin, G. S., Fisher,
J. A., Fuelberg, H. E., Hecobian, A., Knapp, D. J., Mikoviny, T., Riemer, D., Sachse, G. W., Sessions, W., Weber, R. J., Weinheimer, A. J., Wisthaler, A., and Jimenez, J. L.: Effects of aging on organic aerosol from open biomass burning smoke in aircraft and laboratory studies, Atmos. Chem. Phys., 11, 12049-12064, doi:10.5194/acp-11-12049-2011, 2011.

DeCarlo, P. F., Kimmel, J. R., Trimborn, A., Northway, M. J., Jayne, J. T., Aiken, A. C., Gonin, M., Fuhrer, K., Horvath, T., Docherty, K. S., Worsnop, D. R., and Jimenez, J. L.: Field-deployable, high-resolution, time-of-flight aerosol mass spectrometer, Anal. Chem., 78, 8281-8289, 2006.

DeCarlo, P. F., Ulbrich, I. M., Crounse, J., de Foy, B., Dunlea, E. J., Aiken, A. C., Knapp, D., Weinheimer, A. J., Campos, T., Wennberg, P. O., and Jimenez, J. L.: Investigation of the sources and processing of organic aerosol over the Central Mexican Plateau from aircraft measurements during MILAGRO, Atmos. Chem. Phys., 10, 5257-5280, doi:10.5194/acp-10-52572010, 2010.

De Gouw, J. and Jimenez, J. L.: Organic Aerosols in the Earth's Atmosphere, Environ. Sci. Technol., 43, 7614-7618, doi:10.1021/es9006004, 2009.

De Gouw, J. A., Warneke, C., Stohl, A., Wollny, A. G., Brock, C. A., Cooper, O. R., Holloway, J. S., Trainer, M., Fehsenfeld, F. C., Atlas, E. L., Donnelly, S. G., Stroud, V., and Lueb, A.: Volatile organic compounds composition of merged and aged forest fire plumes from Alaska and western Canada, J. Geophys. Res.-Atmos., 111, D10303, doi:10.1029/2005JD006175, 2006.

Dennison, P. E., Brewer, S. C., Arnold, J. D., and Moritz, M. A.: Large wildfire trends in the western United States, 1984-2011, Geophys. Res. Lett., 41, 2928-2933, doi:10.1002/2014GL059576, 2014.

Dinar, E., Mentel, T. F., and Rudich, Y.: The density of humic acids and humic like substances (HULIS) from fresh and aged wood burning and pollution aerosol particles, Atmos. Chem. Phys., 6, 5213-5224, doi:10.5194/acp-6-5213-2006, 2006.

Draxler, R. R. and Hess, G. D.: An overview of the Hysplit-4 modeling system for trajectories, dispersion, and deposition, Aust. Meteorol. Mag., 47, 295-308, 1998.

Engelhart, G. J., Hennigan, C. J., Miracolo, M. A., Robinson, A. L., and Pandis, S. N.: Cloud condensation nuclei activity of fresh primary and aged biomass burning aerosol, Atmos. Chem. Phys., 12, 7285-7293, doi:10.5194/acp-12-7285-2012, 2012.

Engling, G., Herckes, P., Kreidenweis, S. M., Malm, W. C., and Collett Jr., J. L.: Composition of the fine organic aerosol in Yosemite National Park during the 2002 Yosemite Aerosol Characterization Study, Atmos. Environ., 40, 2959 2972, doi:10.1016/j.atmosenv.2005.12.041, 2006.

Fierz, M., Vernooij, M. G. C., and Burtscher, H.: An improved low-flow thermodenuder, J. Aerosol Sci., 38, 1163-1168, doi:10.1016/j.jaerosci.2007.08.006, 2007.

Ge, X., Shaw, S. L., and Zhang, Q.: Toward Understanding Amines and Their Degradation Products from Postcombustion $\mathrm{CO}_{2}$ Capture Processes with Aerosol Mass Spectrometry, Environ. Sci. Technol., 48, 5066-5075, doi:10.1021/es4056966, 2014.

Ge, X. L., Setyan, A., Sun, Y. L., and Zhang, Q.: Primary and secondary organic aerosols in Fresno, California during wintertime: Results from high resolution aerosol mass spectrometry, J. Geophys. Res.-Atmos., 117, D19301, doi:10.1029/2012JD018026, 2012a. 
Ge, X. L., Zhang, Q., Sun, Y. L., Ruehl, C. R., and Setyan, A.: Effect of aqueous-phase processing on aerosol chemistry and size distributions in Fresno, California, during wintertime, Environ. Chem., 9, 221-235, doi:10.1071/EN11168, 2012b.

Gilardoni, S., Massoli, P., Paglione, M., Giulianelli, L., Carbone, C., Rinaldi, M., Decesari, S., Sandrini, S., Costabile, F., Gobbi, G. P., Pietrogrande, M. C., Visentin, M., Scotto, F., Fuzzi, S., and Facchini, M. C.: Direct observation of aqueous secondary organic aerosol from biomass-burning emissions, P. Natl. Acad. Sci. USA, 113, 10013-10018, doi:10.1073/pnas.1602212113, 2016.

Grieshop, A. P., Donahue, N. M., and Robinson, A. L.: Laboratory investigation of photochemical oxidation of organic aerosol from wood fires 2: analysis of aerosol mass spectrometer data, Atmos. Chem. Phys., 9, 2227-2240, doi:10.5194/acp-9-2227-2009, 2009.

Hallar, A. G., Petersen, R., Andrews, E., Michalsky, J., McCubbin, I. B., and Ogren, J. A.: Contributions of dust and biomass burning to aerosols at a Colorado mountain-top site, Atmos. Chem. Phys., 15, 13665-13679, doi:10.5194/acp-15-13665-2015, 2015.

Hennigan, C. J., Miracolo, M. A., Engelhart, G. J., May, A. A., Presto, A. A., Lee, T., Sullivan, A. P., McMeeking, G. R., Coe, H., Wold, C. E., Hao, W.-M., Gilman, J. B., Kuster, W. C., De Gouw, J., Schichtel, B. A., Collett Jr., J. L., Kreidenweis, S. M., and Robinson, A. L.: Chemical and physical transformations of organic aerosol from the photo-oxidation of open biomass burning emissions in an environmental chamber, Atmos. Chem. Phys., 11, 7669-7686, doi:10.5194/acp-11-7669-2011, 2011.

Heringa, M. F., DeCarlo, P. F., Chirico, R., Tritscher, T., Dommen, J., Weingartner, E., Richter, R., Wehrle, G., Prévôt, A. S. H., and Baltensperger, U.: Investigations of primary and secondary particulate matter of different wood combustion appliances with a high-resolution time-of-flight aerosol mass spectrometer, Atmos. Chem. Phys., 11, 5945-5957, doi:10.5194/acp-11-59452011, 2011.

Huffman, J. A., Docherty, K. S., Aiken, A. C., Cubison, M. J., U1brich, I. M., DeCarlo, P. F., Sueper, D., Jayne, J. T., Worsnop, D. R., Ziemann, P. J., and Jimenez, J. L.: Chemically-resolved aerosol volatility measurements from two megacity field studies, Atmos. Chem. Phys., 9, 7161-7182, doi:10.5194/acp-9-71612009, 2009.

IPCC: Climate Change 2013: The Physical Science Basis, Cambridge University Press, Cambridge, United Kingdom and New York, NY, USA, 2013.

Jaffe, D., Hafner, W., Chand, D., Westerling, A., and Spracklen, D.: Interannual Variations in $\mathrm{PM}_{2.5}$ due to Wildfires in the Western United States, Environ. Sci. Technol., 42, 2812-2818, doi:10.1021/es702755v, 2008.

Jaffe, D. A. and Wigder, N. L.: Ozone production from wildfires: A critical review, Atmos. Environ., 51, 1-10, doi:10.1016/j.atmosenv.2011.11.063, 2012.

Jolleys, M. D., Coe, H., McFiggans, G., McMeeking, G. R., Lee, T., Kreidenweis, S. M., Collett, J. L., and Sullivan, A. P.: Organic aerosol emission ratios from the laboratory combustion of biomass fuels, J. Geophys. Res.-Atmos., 119, 12850-12871, doi:10.1002/2014JD021589, 2014.

Jolleys, M. D., Coe, H., McFiggans, G., Taylor, J. W., O'Shea, S. J., Le Breton, M., Bauguitte, S. J.-B., Moller, S., Di Carlo, P., Aruffo, E., Palmer, P. I., Lee, J. D., Percival, C. J., and Gallagher, M. W.: Properties and evolution of biomass burning or- ganic aerosol from Canadian boreal forest fires, Atmos. Chem Phys., 15, 3077-3095, doi:10.5194/acp-15-3077-2015, 2015.

Kondo, Y., Matsui, H., Moteki, N., Sahu, L., Takegawa, N., Kajino, M., Zhao, Y., Cubison, M. J., Jimenez, J. L., Vay, S., Diskin, G. S., Anderson, B., Wisthaler, A., Mikoviny, T., Fuelberg, H. E., Blake, D. R., Huey, G., Weinheimer, A. J., Knapp, D. J., and Brune, W. H.: Emissions of black carbon, organic, and inorganic aerosols from biomass burning in North America and Asia in 2008, J. Geophys. Res.-Atmos., 116, D08204, doi:10.1029/2010JD015152, 2011.

Kroll, J. H., Donahue, N. M., Jimenez, J. L., Kessler, S. H., Canagaratna, M. R., Wilson, K. R., Altieri, K. E., Mazzoleni, L. R., Wozniak, A. S., Bluhm, H., Mysak, E. R., Smith, J. D., Kolb, C. E., and Worsnop, D. R.: Carbon oxidation state as a metric for describing the chemistry of atmospheric organic aerosol, Nat. Chem., 3, 133-139, doi:10.1038/nchem.948, 2011.

Lee, A. K. Y., Willis, M. D., Healy, R. M., Wang, J. M., Jeong, C.-H., Wenger, J. C., Evans, G. J., and Abbatt, J. P. D.: Singleparticle characterization of biomass burning organic aerosol (BBOA): evidence for non-uniform mixing of high molecular weight organics and potassium, Atmos. Chem. Phys., 16, 55615572, doi:10.5194/acp-16-5561-2016, 2016.

Lewis, K. A., Arnott, W. P., Moosmüller, H., Chakrabarty, R. K., Carrico, C. M., Kreidenweis, S. M., Day, D. E., Malm, W. C., Laskin, A., Jimenez, J. L., Ulbrich, I. M., Huffman, J. A., Onasch, T. B., Trimborn, A., Liu, L., and Mishchenko, M. I.: Reduction in biomass burning aerosol light absorption upon humidification: roles of inorganically-induced hygroscopicity, particle collapse, and photoacoustic heat and mass transfer, Atmos. Chem. Phys., 9, 8949-8966, doi:10.5194/acp-9-8949-2009, 2009.

Liu, Y., Goodrick, S., and Heilman, W.: Wildland fire emissions, carbon, and climate: Wildfire-climate interactions, Forest Ecol. Manag., 317, 80-96, doi:10.1016/j.foreco.2013.02.020, 2014.

Maudlin, L. C., Wang, Z., Jonsson, H. H., and Sorooshian, A.: Impact of wildfires on size-resolved aerosol composition at a coastal California site, Atmos. Environ., 119, 59-68, doi:10.1016/j.atmosenv.2015.08.039, 2015.

May, A. A., Levin, E. J. T., Hennigan, C. J., Riipinen, I., Lee, T., Collett, J. L., Jimenez, J. L., Kreidenweis, S. M., and Robinson, A. L.: Gas-particle partitioning of primary organic aerosol emissions: 3. Biomass burning, J. Geophys. Res.-Atmos., 118, 11327-11338, doi:10.1002/jgrd.50828, 2013.

May, A. A., Lee, T., McMeeking, G. R., Akagi, S., Sullivan, A. P., Urbanski, S., Yokelson, R. J., and Kreidenweis, S. M.: Observations and analysis of organic aerosol evolution in some prescribed fire smoke plumes, Atmos. Chem. Phys., 15, 6323-6335, doi:10.5194/acp-15-6323-2015, 2015.

Middlebrook, A. M., Bahreini, R., Jimenez, J. L., and Canagaratna, M. R.: Evaluation of Composition-Dependent Collection Efficiencies for the Aerodyne Aerosol Mass Spectrometer using Field Data, Aerosol Sci. Tech., 46, 258-271, doi:10.1080/02786826.2011.620041, 2012.

Ortega, A. M., Day, D. A., Cubison, M. J., Brune, W. H., Bon, D., De Gouw, J. A., and Jimenez, J. L.: Secondary organic aerosol formation and primary organic aerosol oxidation from biomass-burning smoke in a flow reactor during FLAME-3, Atmos. Chem. Phys., 13, 11551-11571, doi:10.5194/acp-1311551-2013, 2013. 
Paatero, P. and Tapper, U.: Positive matrix factorization a nonnegative factor model with optimal utilization of error-estimates of data values, Environmetrics, 5, 111-126, doi:10.1002/env.3170050203, 1994.

Paciga, A., Karnezi, E., Kostenidou, E., Hildebrandt, L., Psichoudaki, M., Engelhart, G. J., Lee, B.-H., Crippa, M., Prévôt, A. S. H., Baltensperger, U., and Pandis, S. N.: Volatility of organic aerosol and its components in the megacity of Paris, Atmos. Chem. Phys., 16, 2013-2023, doi:10.5194/acp-16-20132016, 2016.

Petters, M. D., Carrico, C. M., Kreidenweis, S. M., Prenni, A. J., DeMott, P. J., Collett, J. L., and Moosmüller, H.: Cloud condensation nucleation activity of biomass burning aerosol, J. Geophys. Res.-Atmos., 114, D22205, doi:10.1029/2009JD012353, 2009.

Rinaldi, M., Gilardoni, S., Paglione, M., Sandrini, S., Fuzzi, S., Massoli, P., Bonasoni, P., Cristofanelli, P., Marinoni, A., Poluzzi, V., and Decesari, S.: Organic aerosol evolution and transport observed at Mt. Cimone (2165 ma.s.l.), Italy, during the PEGASOS campaign, Atmos. Chem. Phys., 15, 11327-11340, doi:10.5194/acp-15-11327-2015, 2015.

Spracklen, D. V., Mickley, L. J., Logan, J. A., Hudman, R. C., Yevich, R., Flannigan, M. D., and Westerling, A. L.: Impacts of climate change from 2000 to 2050 on wildfire activity and carbonaceous aerosol concentrations in the western United States, J. Geophys. Res.-Atmos., 114, D20301, doi:10.1029/2008JD010966, 2009.

Sun, Y., Zhang, Q., Macdonald, A. M., Hayden, K., Li, S. M., Liggio, J., Liu, P. S. K., Anlauf, K. G., Leaitch, W. R., Steffen, A., Cubison, M., Worsnop, D. R., van Donkelaar, A., and Martin, R. V.: Size-resolved aerosol chemistry on Whistler Mountain, Canada with a high-resolution aerosol mass spectrometer during INTEX-B, Atmos. Chem. Phys., 9, 3095-3111, doi:10.5194/acp9-3095-2009, 2009.

Sun, Y. L., Zhang, Q., Schwab, J. J., Yang, T., Ng, N. L., and Demerjian, K. L.: Factor analysis of combined organic and inorganic aerosol mass spectra from high resolution aerosol mass spectrometer measurements, Atmos. Chem. Phys., 12, 8537-8551, doi:10.5194/acp-12-8537-2012, 2012

Timonen, H., Jaffe, D. A., Wigder, N., Hee, J., Gao, H., Pitzman, L., and Cary, R. A.: Sources of carbonaceous aerosol in the free troposphere, Atmos. Environ., 92, 146-153, doi:10.1016/j.atmosenv.2014.04.014, 2014.

Ulbrich, I. M., Canagaratna, M. R., Zhang, Q., Worsnop, D. R., and Jimenez, J. L.: Interpretation of organic components from Positive Matrix Factorization of aerosol mass spectrometric data, Atmos. Chem. Phys., 9, 2891-2918, doi:10.5194/acp-9-2891-2009, 2009

Weimer, S., Alfarra, M. R., Schreiber, D., Mohr, M., Prévôt, A. S. $\mathrm{H}$., and Baltensperger, U.: Organic aerosol mass spectral signatures from wood-burning emissions: Influence of burning conditions and wood type, J. Geophys. Res.-Atmos., 113, D10304, doi:10.1029/2007JD009309, 2008.

Weiss-Penzias, P., Jaffe, D. A., Swartzendruber, P., Dennison, J. B., Chand, D., Hafner, W., and Prestbo, E.: Observations of Asian air pollution in the free troposphere at Mount Bachelor Observatory during the spring of 2004, J. Geophys. Res.-Atmos., 111, D10304, doi:10.1029/2005JD006522, 2006.
Westerling, A. L., Hidalgo, H. G., Cayan, D. R., and Swetnam, T. W.: Warming and Earlier Spring Increase Western U.S. Forest Wildfire Activity, Science, 313, 940-943, doi:10.1126/science.1128834, 2006.

Wigder, N. L., Jaffe, D. A., and Saketa, F. A.: Ozone and particulate matter enhancements from regional wildfires observed at Mount Bachelor during 2004-2011, Atmos. Environ., 75, 24-31, doi:10.1016/j.atmosenv.2013.04.026, 2013.

Yokelson, R. J., Crounse, J. D., DeCarlo, P. F., Karl, T., Urbanski, S., Atlas, E., Campos, T., Shinozuka, Y., Kapustin, V., Clarke, A. D., Weinheimer, A., Knapp, D. J., Montzka, D. D., Holloway, J., Weibring, P., Flocke, F., Zheng, W., Toohey, D., Wennberg, P. O., Wiedinmyer, C., Mauldin, L., Fried, A., Richter, D., Walega, J., Jimenez, J. L., Adachi, K., Buseck, P. R., Hall, S. R., and Shetter, R.: Emissions from biomass burning in the Yucatan, Atmos. Chem. Phys., 9, 5785-5812, doi:10.5194/acp-9-5785-2009, 2009.

Young, D. E., Allan, J. D., Williams, P. I., Green, D. C., Harrison, R. M., Yin, J., Flynn, M. J., Gallagher, M. W., and Coe, H.: Investigating a two-component model of solid fuel organic aerosol in London: processes, $\mathrm{PM}_{1}$ contributions, and seasonality, Atmos. Chem. Phys., 15, 2429-2443, doi:10.5194/acp-152429-2015, 2015.

Young, D. E., Kim, H., Parworth, C., Zhou, S., Zhang, X., Cappa, C. D., Seco, R., Kim, S., and Zhang, Q.: Influences of emission sources and meteorology on aerosol chemistry in a polluted urban environment: results from DISCOVER-AQ California, Atmos. Chem. Phys., 16, 5427-5451, doi:10.5194/acp-16-54272016, 2016.

Yu, L., Smith, J., Laskin, A., George, K. M., Anastasio, C., Laskin, J., Dillner, A. M., and Zhang, Q.: Molecular transformations of phenolic SOA during photochemical aging in the aqueous phase: competition among oligomerization, functionalization, and fragmentation, Atmos. Chem. Phys., 16, 4511-4527, doi:10.5194/acp-16-4511-2016, 2016.

Zauscher, M. D., Wang, Y., Moore, M. J. K., Gaston, C. J., and Prather, K. A.: Air Quality Impact and Physicochemical Aging of Biomass Burning Aerosols during the 2007 San Diego Wildfires, Environ. Sci. Technol., 47, 7633-7643, doi:10.1021/es4004137, 2013.

Zhang, Q., Canagaratna, M. R., Jayne, J. T., Worsnop, D. R., and Jimenez, J. L.: Time- and size-resolved chemical composition of submicron particles in Pittsburgh: Implications for aerosol sources and processes, J. Geophys. Res.-Atmos., 110, D07S09, doi:10.1029/2004JD004649, 2005.

Zhang, Q., Jimenez, J. L., Canagaratna, M. R., Ulbrich, I. M., Ng, N. L., Worsnop, D. R., and Sun, Y. L.: Understanding atmospheric organic aerosols via factor analysis of aerosol mass spectrometry: a review, Anal. Bioanal. Chem., 401, 3045-3067, doi:10.1007/s00216-011-5355-y, 2011.

Zhou, S., Collier, S., Xu, J., Mei, F., Wang, J., Lee, Y.-N., Sedlacek, A. J., Springston, S. R., Sun, Y., and Zhang, Q.: Influences of upwind emission sources and atmospheric processing on aerosol chemistry and properties at a rural location in the Northeastern U.S., J. Geophys. Res.-Atmos., 121, 6049-6065, doi:10.1002/2015JD024568, 2016. 